\title{
Role of MCPIP1 in the Endothelial- Mesenchymal Transition Induced by Silica
}

\author{
Jie Chao a,b,c,d Xingang Wanga,d Yuxia Zhanga Tiebing Zhue Wei Zhang ${ }^{a}$ \\ Zewei Zhou a,d Jian Yang ${ }^{d}$ Bing Han ${ }^{d}$ Yusi Cheng ${ }^{a}$ Xiaojie Tu ${ }^{a}$ Honghong Yao ${ }^{c, d}$ \\ aDepartment of Physiology, School of Medicine, Southeast University, Nanjing, Jiangsu, ${ }^{\mathrm{b}}$ Department \\ of Respiration, Zhongda Hospital, School of Medicine, Southeast University, Nanjing, 'Key Laboratory \\ of Developmental Genes and Human Disease, Southeast University, Nanjing, dDepartment of \\ Pharmacology, School of Medicine, Southeast University, Nanjing, eDepartment of Cardiology, The First \\ Affiliated Hospital of Nanjing Medical University, Nanjing, China
}

\section{Key Words}

Endothelial-mesenchymal transition $・$ MCPIP1 1 Silicosis $・$ Fibrosis $•$ Autophagy

\begin{abstract}
Background: Silicosis is characterized by the accumulation of fibroblasts and the excessive deposition of extracellular matrix. Fibroblast generation via endothelial-mesenchymal transition (EndMT) is one process responsible for this accumulation of fibroblasts. However, the mechanisms underlying EndMT remain unknown. Methods: Human umbilical vein endothelial cells (HUVECs) were exposed to $\mathrm{SiO}_{2}\left(50 \mu \mathrm{g} / \mathrm{cm}^{2}\right)$. Specific endothelial and mesenchymal markers were evaluated using immunofluorescence and western blot analysis. Functional changes were evaluated by analyzing cell migration and proliferation. LC3-adenovirus transfections were performed, and changes in autophagy were measured using a marker of autophagy. Results: $\mathrm{SiO}_{2}$ induced decreases in the endothelial cell-specific markers in HUVECs while dramatically increasing mesenchymal cell product levels and mesenchymal functions. Although MCPIP1 expression increased in parallel with the increase in specific mesenchymal cell products, the MCPIP1 expression level was not consistent with the observed decrease in specific endothelial marker expression. Autophagy mediated the effects of MCPIP1, as rapamycin and 3-MA enhanced and attenuated the effect of $\mathrm{SiO}_{2}$ on $\mathrm{HUVECs}$, respectively. MAPKs and the PI3K/Akt pathway were involved in the regulation of MCPIP1 by $\mathrm{SiO}_{2}$, and Pyk2 and MLC-2 mediated cell migration. Conclusion: Our findings reveal a new potential function of MCPIP1, suggesting a possible mechanism of fibrosis in pulmonary silicosis.
\end{abstract}

(C) 2016 The Author(s)

Published by S. Karger AG, Basel

\section{Introduction}

Silicosis is a disease that is characterized by progressive pulmonary fibrotic reactions [1-4]. The accumulation of activated fibroblasts and the excessive deposition of extracellular

J. Chao, X. Wang and Y. Zhang contributed equally to this work.

Jie Chao, Ph.D., and Honghong Yao, Ph.D. Department of Physiology, and Department of Pharmacology, Medical School of

Southeast University, 87 Dingjiaqiao Rd, Nanjing, Jiangsu, 210009 (China)

E-Mail chaojie@seu.edu.cn / yaohh@seu.edu.cn 


\section{Cellular Physiology Cell Physiol Biochem 2016;40:309-325 \begin{tabular}{ll|l} 
and Biochemistry & $\begin{array}{l}\text { DOI: 10.1159/000452547 } \\
\text { Published online: November 21, } 2016\end{array}$ & $\begin{array}{l}\text { C } 2016 \text { The Author(s). Published by S. Karger AG, Basel } \\
\text { www.karger.com/cpb }\end{array}$ \\
\hline
\end{tabular} Chao et al.: MCPIP1 Promotes EndMT in Silicosis}

matrix (ECM) contribute to tissue reconstruction and fibrosis [5]. Traditionally, embryonic mesenchymal cells are considered to be the sources of intrapulmonary fibroblasts via cell proliferation [6]. However, many studies have indicated that during pulmonary fibrosis, endothelial cells can also contribute to the accumulation of fibroblasts via endothelialmesenchymal transition (EndMT) [7-10].

EndMT has been observed during fibrosis in organs including the kidneys [11], liver, and heart [12] as well as in patients with diabetes [13] and metastatic tumors [12]. EndMT can occur during physiological and pathological processes. As a consequence of EndMT, endothelial cells lose their expression of specific endothelial markers, acquire a mesenchymal phenotype, and begin to express mesenchymal cell products, such as type I collagen, type III collagen and $\alpha$-smooth muscle actin ( $\alpha$-SMA) [14].

Many factors can induce the EndMT process. The most important of these is transforming growth factor- $\beta$ (TGF- $\beta$ ), which promotes EndMT through the Smad2/3 and Smad1/5/8 signaling pathways [15]. In contrast to our detailed knowledge of growth factors and their signaling pathways, the roles of chemokines in EndMT are poorly characterized. Previous data produced by our laboratory suggest that monocyte chemotactic protein-induced protein 1 (MCPIP1) is involved in the regulation of cell proliferation and migration via an miR-9mediated mechanism. Moreover, we found that MCPIP1 played an important role in the $\mathrm{SiO}_{2}$-induced proliferation and migration of pulmonary macrophages and fibroblasts, which are the important effectors of fibrosis [16-20]. On the other hand, MCPIP1 has been shown to be involved in enhancing angiogenic activity in human umbilical vein endothelial cells (HUVECs) and murine bone marrow-derived mesenchymal stem cells [21-23]. Additionally, whether MCPIP1 mediates EndMT in silicosis remains unknown.

In this study, we demonstrated that MCPIP1 causes endothelial cells that are exposed to silica to undergo EndMT via autophagy, and we show that MCPIP1, a chemokine family member, played a key role in EndMT. Furthermore, our findings may provide researchers with a new understanding of and new methods for treating pulmonary fibrosis associated with silicosis.

\section{Materials and Methods}

\section{Reagents}

$\mathrm{SiO}_{2}$ was obtained from Sigma ${ }^{\circledR}$ (S5631), and $80 \%$ of the particles were less than $5 \mu \mathrm{m}$ in diameter. The particles were selected via sedimentation in a vertical glass tube according to Stokes' law, which yielded particles of 1-5 $\mu \mathrm{m}$ in diameter [24]. The particles were then acid-hydrolyzed and baked overnight $\left(200^{\circ} \mathrm{C}\right.$ for $\left.16 \mathrm{~h}\right)$. The silica samples used for the cell experiments were sterilized by autoclaving and then suspended in sterile normal saline (NS) at a concentration of $5 \mathrm{mg} / \mathrm{ml}$. Fetal bovine serum (FBS), normal goat serum (NGS) and Dulbecco's modified Eagle's medium (DMEM; \#1200-046) were purchased from Life Technologies ${ }^{\mathrm{TM}}$, and PenStrep (15140-122) was obtained from Fisher Scientific. PureCol $\circledast$ type I bovine collagen $(3 \mathrm{mg} / \mathrm{mL}$ ) was obtained from Advanced Biomatrix. Antibodies against MCPIP1 (SC136750, goat, 1:1000) and $\beta$-actin (SC8432, mouse, 1:2000) were obtained from Santa Cruz Biotechnology ${ }^{\circledR}$, Inc. The collagen I (Col I; BS1530, 1:1000) and collagen III (Col III; BS1531, 1:1000) antibodies were obtained from BioWorld $($. Antibodies against Akt (9272S, 1:1000), p-Akt (9271S, 1:1000), ERK (9107S, 1:1000), p-ERK (9101S, 1:1000), JNK (9258S, 1:1000), p-JNK (9251S, 1:1000), p38 (9212S, 1:1000), p-p38 (9211S, 1:1000) and $\alpha$-SMA (14968S, 1:1000) were obtained from Cell Signaling $®$, Inc.

\section{Cell culture}

HUVECs were purchased from ScienCell ${ }^{\circledR}$ and maintained in T75 flasks in DMEM supplemented with 10\% FBS. HUVECs from passages 3-7 (P3-7) were stored in liquid nitrogen. A vial of P3-7 HUVECs was thawed, plated, and passaged upon confluence to perform each experiment, and each experiment was performed using HUVECs between P10 and P15 [23].

\section{KARGER}




\section{Cellular Physiology Cell Physiol Biochem 2016;40:309-325 \begin{tabular}{ll|l|l} 
and Biochemistry $10.1159 / 000452547$ & $\begin{array}{l}\text { O 2016 The Author(s). Published by S. Karger AG, Basel } \\
\text { www.karger.com/cpb }\end{array}$ \\
\cline { 2 - 4 }
\end{tabular} Chao et al.: MCPIP1 Promotes EndMT in Silicosis}

\section{Lentiviral transduction of HUVECS with GFP}

HUVECs were transduced using LV-GFP lentiviruses (Hanbio Inc., Shanghai, China) as previously described [25]. Briefly, P3-4 HUVECs were cultured in 24-well plates at $1 \times 10^{4}$ cells/well in DMEM supplemented with 10\% FBS for $48 \mathrm{~h}$. The medium was then replaced with $1 \mathrm{ml}$ of fresh medium and $8 \mu \mathrm{g} /$ $\mathrm{ml}$ polybrene. Then, $100 \mu \mathrm{L}$ of lentivirus solution $(107 \mathrm{IU} / \mathrm{ml})$ was added to each well, and the cells were incubated at $37^{\circ} \mathrm{C}$ in $5 \% \mathrm{CO}_{2}$ for $24 \mathrm{~h}$. After the incubation period, the treatment medium was replaced with fresh DMEM supplemented with $10 \% \mathrm{FBS}$, and the cells were cultured at $37^{\circ} \mathrm{C}$ in $5 \% \mathrm{CO}_{2}$ until they reached $>50 \%$ confluence. Transduced cells were selected using puromycin as follows: the medium was replaced with DMEM containing $10 \mu \mathrm{g} / \mathrm{ml}$ puromycin and $10 \% \mathrm{FBS}$, and the cells were cultured at $37^{\circ} \mathrm{C}$ in $5 \% \mathrm{CO}_{2}$ for $24 \mathrm{~h}$. The cells were then washed twice with fresh DMEM supplemented with $10 \%$ FBS. Purified transduced HUVEC cultures were expanded and/or stored in liquid nitrogen as previously described [26].

\section{Transduction of HUVECs with dually fluorescent mRFP-GFP-MAP1LC3-adenovirus}

The relative level of cellular autophagy was quantified using the fluorescent mRFP-GFP-MAP1LC3adenovirus transduction technique as described by Zhu [23]. Briefly, HUVECs were transfected with dually fluorescent mRFP-GFP-MAP1LC3-adenovirus (Hanbio, Inc., Shanghai, China), which expressed a specific marker of autophagosome formation, to detect autophagy according to the manufacturer's instructions [27]. Five fields from three different cell preparations were chosen for analysis. GFP- and mRFP-expressing spots, which were visualized as fluorescent puncta, and DAPI-stained nuclei were counted manually. The number of GFP- and mRFP-expressing spots per cell was determined by dividing the total number of spots by the number of nuclei in each field.

\section{MTT assay}

Cell viability was measured using the 3-(4,5-dmethylthiazol-2-yl)-2,5-diphenyl tetrazolium bromide (MTT) assay. Briefly, the cells were collected and seeded in 96-well plates. Different seeding densities were used at the beginning of the experiments. The cells were exposed to $\mathrm{SiO}_{2}\left(50 \mu \mathrm{g} / \mathrm{cm}^{2}\right)$. The cells were incubated for different periods of time (from 24-72 h), and $20 \mu \mathrm{l}$ of MTT dissolved in Hank's balanced salt solution at a final concentration of $5 \mu \mathrm{g} / \mathrm{ml}$ was added to each well. The plates were then incubated in a $5 \% \mathrm{CO}_{2}$ incubator for 1-4 $\mathrm{h}$. Afterwards, the medium was aspirated from each well, and $200 \mu \mathrm{l}$ of dimethyl sulfoxide was added to dissolve the formazan crystals. Finally, the absorbance of each well at reference wavelengths of 570 and $630 \mathrm{~nm}$ was measured using a plate reader. Each experiment was repeated at least three times.

\section{Immunocytochemistry}

HUVECs were fixed in $4 \%$ paraformaldehyde in PBS at $4^{\circ} \mathrm{C}$ overnight. The fixed samples were permeabilized for 30 min at room temperature (RT) with $0.3 \%$ Triton X-100 in PBS. The permeabilized samples were blocked in PBS containing 10\% NGS (Life Technologies) and $0.3 \%$ Triton X-100 at RT for $2 \mathrm{~h}$. The blocked samples were incubated in primary antibodies diluted in PBS containing 10\% NGS and $0.3 \%$ Triton X-100 at $4^{\circ} \mathrm{C}$ overnight. Then, the samples were washed three times with PBS and incubated in donkey anti-rabbit (conjugated to Alexa-Fluor ${ }^{8} 488$ ) and donkey anti-mouse (conjugated to Alexa-Fluor ${ }^{\circledR}$ 576) secondary antibodies for $2 \mathrm{~h}$ at RT. After the samples were washed three times in PBS, they were mounted using mounting solution (Prolong® Gold antifade reagent with DAPI; P36931, Life Technologies). The slides were imaged using a fluorescence microscope (Olympus IX70, Olympus America, Inc., Center Valley, PA, USA).

\section{Western blot analysis}

Immunoblotting was performed as previously described [26], with minor modifications. HUVECs were collected from the culture dishes, washed with PBS and then lysed using a mammalian cell lysis kit (MCL1-1KT, Sigma-Aldrich ${ }^{\circledR}$ ) according to the manufacturer's instructions. The western blot membranes were probed using primary antibodies. Alkaline phosphatase-conjugated goat anti-mouse or anti-rabbit IgG secondary antibodies were then used $(1: 5,000)$. Signals were detected via chemiluminescence (SuperSignal West Dura Chemiluminescent Substrate, Thermo Scientific). Each western blot experiment was repeated using cells from three different donors. A single representative immunoblot is shown in each Figure. 


\section{Cellular Physiology Cell Physiol Biochem 2016;40:309-325 \begin{tabular}{ll|l} 
and Biochemistry & $\begin{array}{l}\text { DOI: 10.1159/000452547 } \\
\text { Published online: November 21, } 2016\end{array}$ & $\begin{array}{l}\text { ( ) 2016 The Author(s). Published by S. Karger AG, Basel } \\
\text { www.karger.com/cpb }\end{array}$ \\
\hline
\end{tabular} Chao et al.: MCPIP1 Promotes EndMT in Silicosis}

Densitometric analysis was performed using ImageJ software, and the results from all of the repeated experiments were combined into one plot.

\section{RNA interference using MCPIP1 siRNA}

RNA interference targeting MCPIP1 was performed using HUVECs as previously described [28], with some modifications. The RNA interference protocol that was applied to individual wells in a 24-well plate was as follows. Briefly, $49 \mu \mathrm{l}$ of serum-free DMEM was combined with $1 \mu \mathrm{l}$ of transfection reagent, and $1 \mu \mathrm{l}$ of siRNA stock solution was added to another aliquot of $49 \mu \mathrm{l}$ of serum-free DMEM. These two solutions were incubated separately at RT for $15 \mathrm{~min}$. The transfection reagent and siRNA solutions were then mixed together, and the resulting solution was incubated at RT for an additional $15 \mathrm{~min}$. HUVECs were seeded at a concentration of $5.0 \times 10^{5}$ cells $/ 100 \mu \mathrm{l} /$ well in serum-free DMEM. Afterwards, the siRNA-vehicle solution was added to the plated cells. The transfected HUVECs were cultured in serum-free DMEM for $24 \mathrm{~h}$. Then, the medium was replaced with DMEM containing 10\% FBS for $48 \mathrm{~h}$ before further experiments were conducted. The knockdown efficiency of the siRNA was determined via western blot analysis at 2 days after transfection.

\section{MCPIP1 plasmid transfection}

The Flag-tagged MCPIP1 expression plasmid was generated by inserting the human MCPIP1 coding fragment into the pCMV-MAT-Tag®-FLAG®-1 vector (Sigma-Aldrich®, catalog number C5989) at its HindIII and BamHI sites. The expressed fusion protein consisted of MCPIP1 with the 15- amino acid MAT-TagFlag sequence attached to the N-terminus of MCPIP1. Plasmid transfection was performed as previously described [29].

\section{In vitro scratch assay}

Cell migratory ability in a 2D culture system was tested via an in vitro scratch assay. Briefly, $1 \times 10^{5}$ HUVECs were seeded in 24-well tissue culture plates and cultured in growth medium for $24 \mathrm{~h}$, at which time the HUVECs were approximately $70-80 \%$ confluent. Using a sterile $200-\mu$ l pipette tip, a straight line was carefully scratched in a single direction in the monolayer across the center of the well while maintaining the tip in a position perpendicular to the plate bottom. A second straight line was scratched perpendicular to the first line to create a cross-shaped gap between the cells within each well. Each well was washed twice with $1 \mathrm{ml}$ of fresh growth medium to remove any detached cells. Digital images of the cell gap were captured at different time points, and the gap width was quantitatively evaluated using ImageJ software.

\section{Nested matrix model and cell migration assay}

A nested collagen matrix model was used as previously described [30], with some modifications. For the nested attached matrix, a standard fibroblast-populated collagen matrix (FPCM) was incubated in an attached state for $72 \mathrm{~h}$ in DMEM containing 10\% FBS. Then, the FPCM was removed from the culture well and placed in a $60-\mu \mathrm{l}$ aliquot of fresh acellular collagen matrix solution (a NeoMatrix solution) that was centered within a 12-mm diameter score on the bottom of a new culture well. Next, a 140- $\mu$ l aliquot of NeoMatrix solution was used to cover the newly transferred FPCM. The NeoMatrix was allowed to polymerize for $1 \mathrm{~h}$ at $37^{\circ} \mathrm{C}$ in $5 \% \mathrm{CO}_{2}$, and $2 \mathrm{ml}$ of DMEM containing $10 \%$ FBS was then added to the well.

Cell migration from the nested FPCM to the acellular NeoMatrix was quantified via fluorescence microscopy at $24 \mathrm{~h}$ after nesting. Digital images (with constant dimensions of $1000 \times 800 \mu \mathrm{m}$ ) of 3-5 randomly selected microscopic fields at the interface of the nested FPCM with the acellular NeoMatrix were captured using an EVOS® FL Cell Imaging microscope (Life Technologies, Grand Island, NY, USA). Cell migration from the nested FPCM was quantified by counting the number of cells that had clearly migrated from the nested matrix to the cell-free matrix. The number of cells per field that had migrated from the nested matrix was averaged across these digital micrographs.

\section{Statistics}

The data are presented as the means \pm SEM. Unpaired numerical data were compared using unpaired t-tests (two groups) or ANOVA (more than two groups), and statistical significance was set at $\mathrm{p}<0.05$.

\section{KARGER}




\section{Cellular Physiology Cell Physiol Biochem 2016;40:309-325

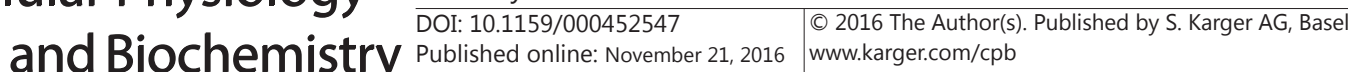

\section{Results}

\section{$\mathrm{SiO}_{2}$ induced EndMT in HUVECS}

EndMT is characterized by the loss of expression of endothelial markers, such as VEGF receptors (VEGFRs), and the acquisition of the ability to produce mesenchymal products, such as Col I, Col III and $\alpha$-SMA [14]. The HUVECs were seeded in 24-well plates (Costar ${ }^{\circledR}$ $3524,1 \times 10^{5} \mathrm{cell} / \mathrm{ml}, 1 \mathrm{ml} /$ well . $\mathrm{SiO}_{2}$ in NS was added to each well at a final concentration of $50 \mu \mathrm{g} / \mathrm{cm}^{2}$. As shown in Fig. $1 \mathrm{~A}-\mathrm{E}, \mathrm{SiO}_{2}$ induced the expression of Col I, Col III and $\alpha$-SMA over 12 hours in a time-dependent manner. In contrast, the expression levels of endothelial markers, except for VEGFR1, were significantly decreased after $12 \mathrm{~h}$ of exposure to $\mathrm{SiO}_{2}$ (Fig. $1 \mathrm{~F}-\mathrm{J})$. These results were confirmed using immunocytochemical staining (Fig. 1A, K). This

Fig. 1. $\mathrm{SiO}_{2}$ induced EndMT in HUVECs. (A) Representative images from immunocytochemistry experiments showing that $\mathrm{SiO}_{2}$ increased the expression of $\mathrm{Col}$ III in HUVECs. Scale bar $=20 \mu \mathrm{m}$. (B). Representative western blot showing the effects of $\mathrm{SiO}_{2}$ on the expression of the mesenchymal markers Col I, Col III and $\alpha$-SMA. Densitometric analyses of five separate experiments suggested that $\mathrm{SiO}_{2}$ induced the expression of Col I (C), Col III (D) and $\alpha$-SMA (E) in a time-dependent manner. ${ }^{*} \mathrm{p}<0.05$ vs the 0 -hour group. (F) Representative western blot showing the effects of $\mathrm{SiO}_{2}$ on the expression of the endothelial markers VEGFR-1, VEGFR-2, VEGFR-3 and VE-cad in HUVECs. Densitometric analyses of five separate experiments indicating the effect of $\mathrm{SiO}_{2}$ exposure on the levels of VEGFR-1 (G), VEGFR-2 (H),

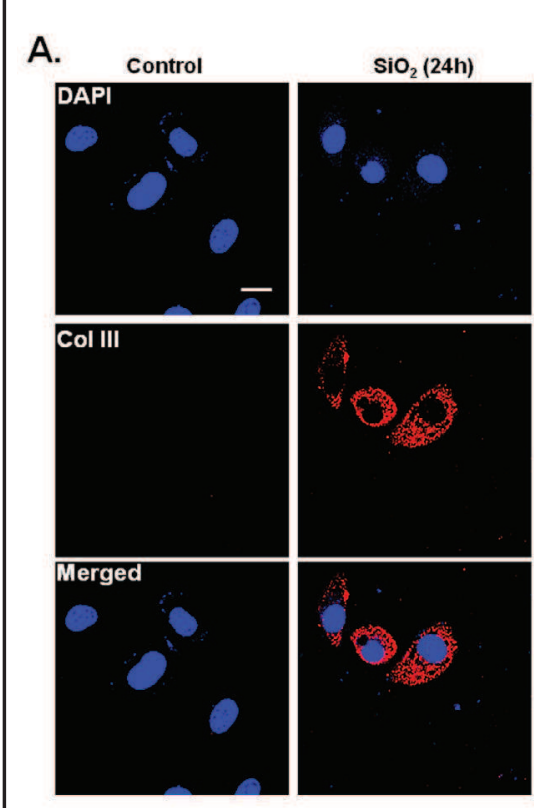

F.

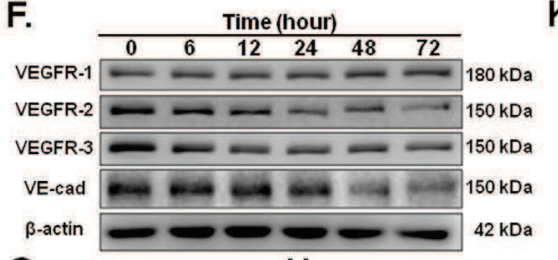

G.

H.

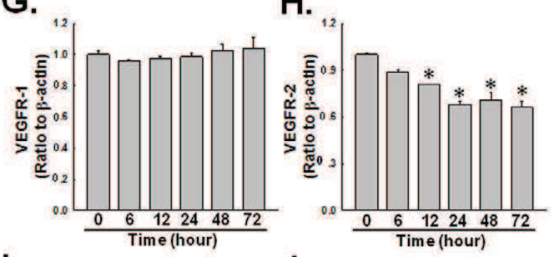

I.

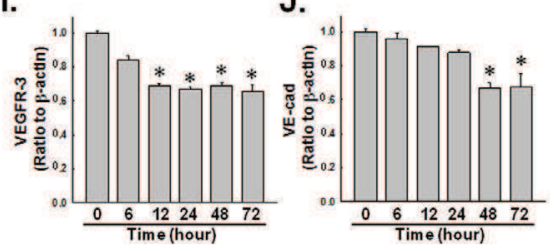

B.

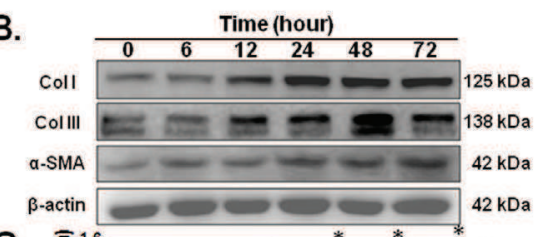

C. 를 1.6

उ.

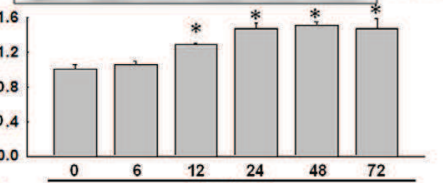

D. $\bar{\Xi}_{4}$\begin{tabular}{rrrrrr}
0 & 6 & 12 & 24 & 48 & 72 \\
\cline { 1 - 5 } & & Time(hour) & $*$
\end{tabular}

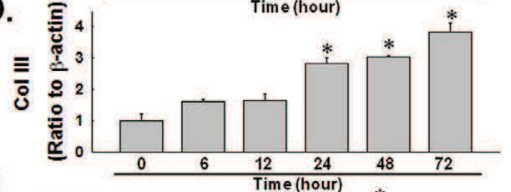

E.

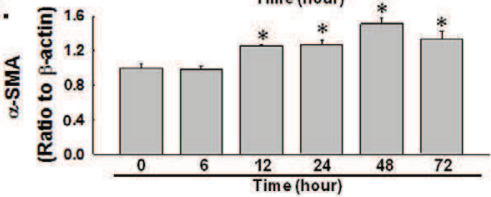

K.
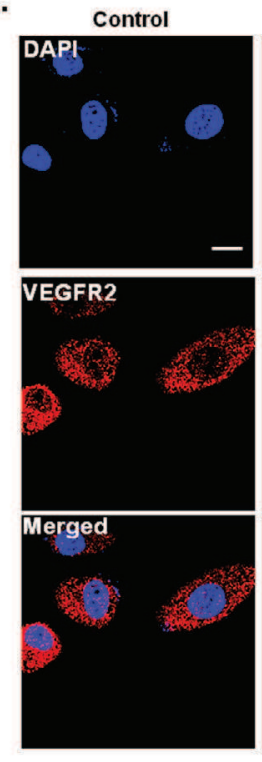

$\mathrm{SiO}_{2}(24 \mathrm{~h})$
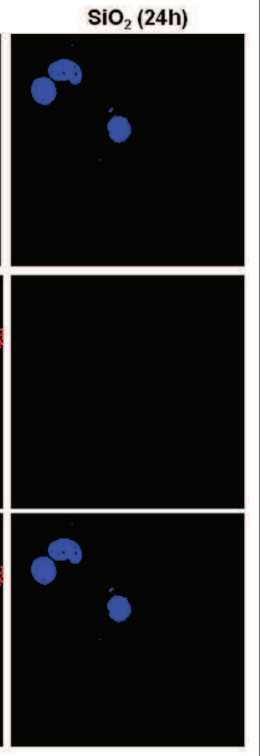

VEGFR-3 (I) and VE-cad (J) * ${ }^{*}<0.05$ vs the 0 -hour group. (K) Representative images from immunocytochemistry experiments showing that $\mathrm{SiO}_{2}$ decreased the expression of VEGFR-2 in HUVECs. Scale bar=20 $\mu \mathrm{m}$. 


\section{Cellular Physiology Cell Physiol Biochem 2016;40:309-325 \begin{tabular}{l|l} 
and Biochemistry Published online: November 21, 2016 & $\begin{array}{l}\text { ( ) 2016 The Author(s). Published by S. Karger AG, Basel } \\
\text { www.karger.com/cpb }\end{array}$ \\
\cline { 2 - 3 }
\end{tabular}}

evidence suggests that the HUVECs that were exposed to $\mathrm{SiO}_{2}$ were induced to change from an endothelial to a mesenchymal phenotype.

MCPIP1 is involved in the $\mathrm{SiO}_{2}$-induced acquisition of mesenchymal characteristics by HUVECS

Previous data from our lab indicated that MCPIP1 played an important role in $\mathrm{SiO}_{2}$ induced fibrosis [16-19]. Here, we sought to determine whether MCPIP1 is also involved in $\mathrm{SiO}_{2}$-induced acquisition of mesenchymal characteristics. First, we measured the expression

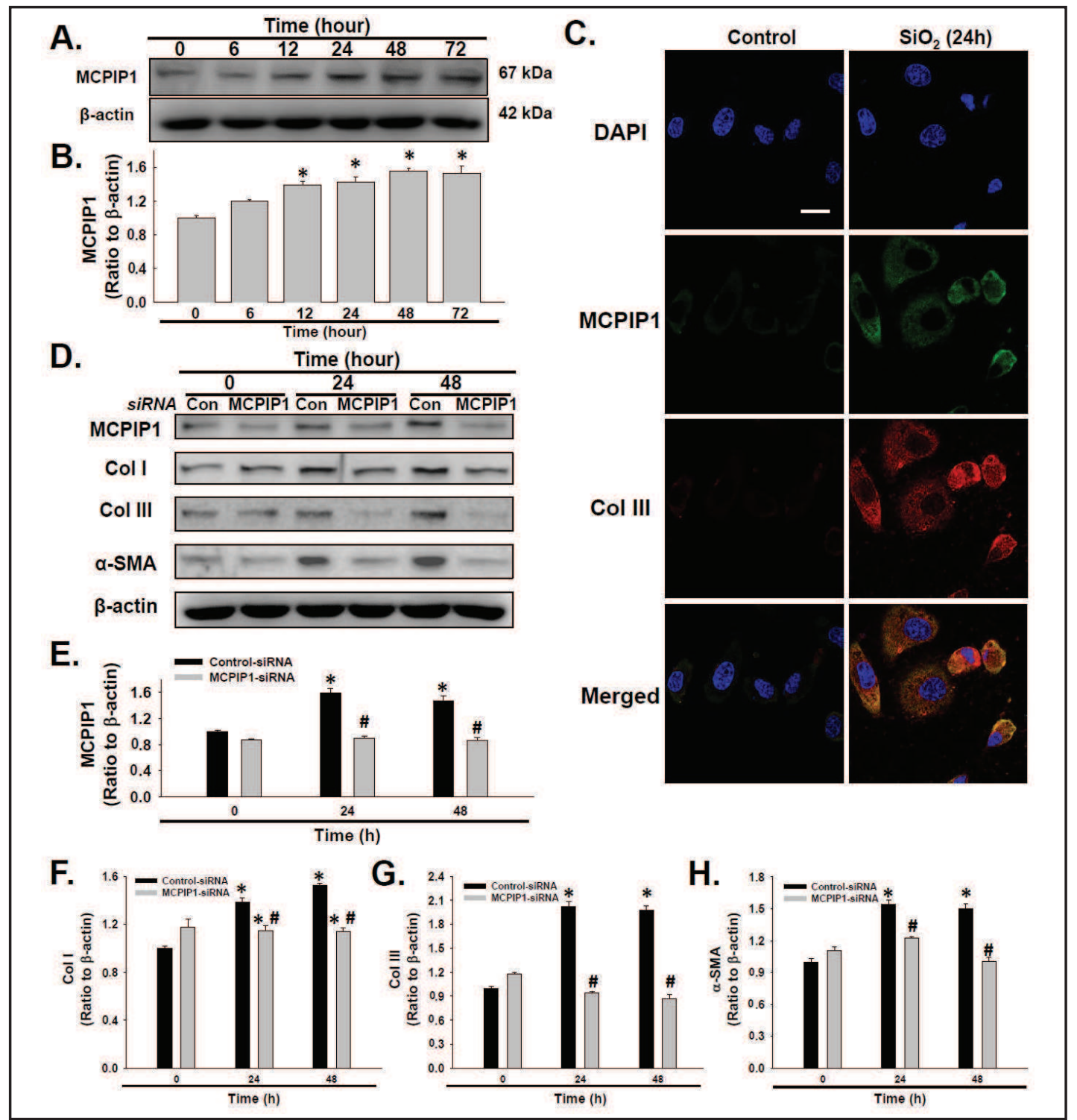

Fig. 2. MCPIP1 is involved in the $\mathrm{SiO}_{2}$-induced acquisition of a mesenchymal phenotype by HUVECs. (A) Representative western blot showing the effects of $\mathrm{SiO}_{2}$ on the expression of MCPIP1 in HUVECs. (B) Densitometric analyses of data from five separate experiments suggested that $\mathrm{SiO}_{2}$ induced $\mathrm{MCPIP}_{1}$ expression in a time-dependent manner. ${ }^{*}$ p $<0.05$ vs the 0 -hour group. (C) Representative immunocytochemical images showing that $\mathrm{SiO}_{2}$ increased the expression of MCPIP1 and Col III in HUVECs. Scale bar=20 $\mu$ m. (D) Representative western blot showing the effects of RNAi targeting MCPIP1 on $\mathrm{SiO}_{2}$-induced Col I, Col III and $\alpha$-SMA expression in HUVECs. The results of densitometric analyses from five separate experiments suggested that RNAi targeting MCPIP1 (E) attenuated the $\mathrm{SiO}_{2}$-induced increase in Col I (F), Col III (G) and $\alpha$-SMA expression $(\mathrm{H})$. $^{*} \mathrm{p}<0.05$ vs the control group at 0 hours; \# $\mathrm{p}<0.05$ vs the $\mathrm{SiO}_{2}$ group at 0 hours. 


\section{Cellular Physiology Cell Physiol Biochem 2016;40:309-325 \begin{tabular}{ll|l} 
DOI: 10.1159/000452547 & O 2016 The Author(s). Published by S. Karger AG, Basel \\
www.karger.com/cpb
\end{tabular}

of MCPIP1 in HUVECs after exposure to $\mathrm{SiO}_{2}$. As shown in Fig. 2A, B, MCPIP1 expression increased in a time-dependent manner in HUVECs that were treated with $\mathrm{SiO}_{2}$. Consistent with the results of western blot analysis, immunocytochemical staining of HUVECs revealed co-localization between MCPIP1 and Col III after 24 hours of exposure to $\mathrm{SiO}_{2}$ (Fig. 2C), indicating an interaction between MCPIP1 and Col III. Furthermore, specifically silencing

Fig. 3. The role of MCPIP1 in the $\mathrm{SiO}_{2}$-induced loss of an endothelial phenotype by HUVECs. (A) Representative images from immunocytochemistry experiments showing that $\mathrm{SiO}_{2}$ increased the expression of MCPIP1 and decreased the expression of VEGFR-2 in HUVECs. Scale bar $=20 \mu \mathrm{m}$. (B) Representative western blot showing the effect of RNAi targeting MCPIP1 on $\mathrm{SiO}_{2}$-induced VEGFR-1, VEGFR-2, VEGFR-3 and VE-cad expression in HUVECs. Densitometric analyses from five separate experiments showing the effect of RNAi targeting MCPIP1 on $\mathrm{SiO}_{2}$-induced VEGFR-1

(C), VEGFR-2 VEGFR-3 (E) and VE-cad expression in HUVECs (F). * $\mathrm{p}<0.05$ vs the control group at 0 hours; \# p<0.05 vs
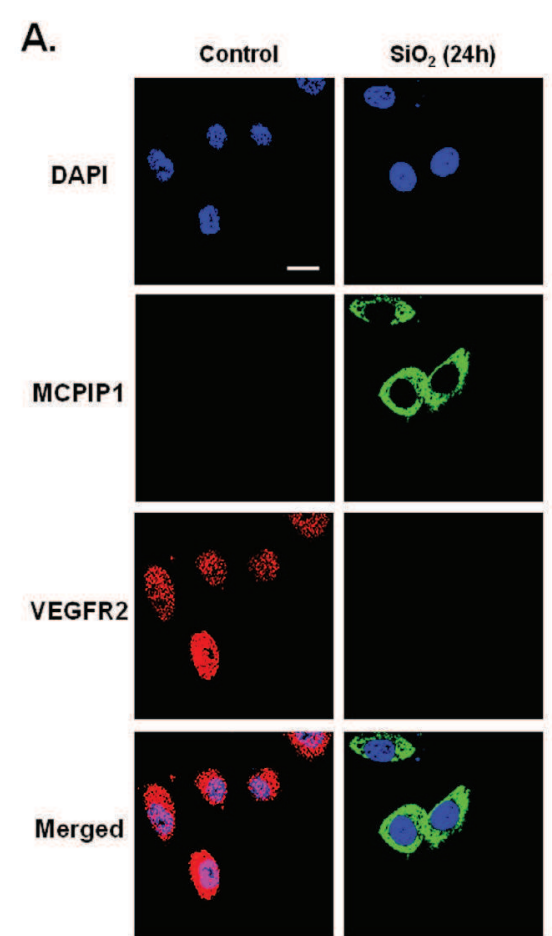

G.
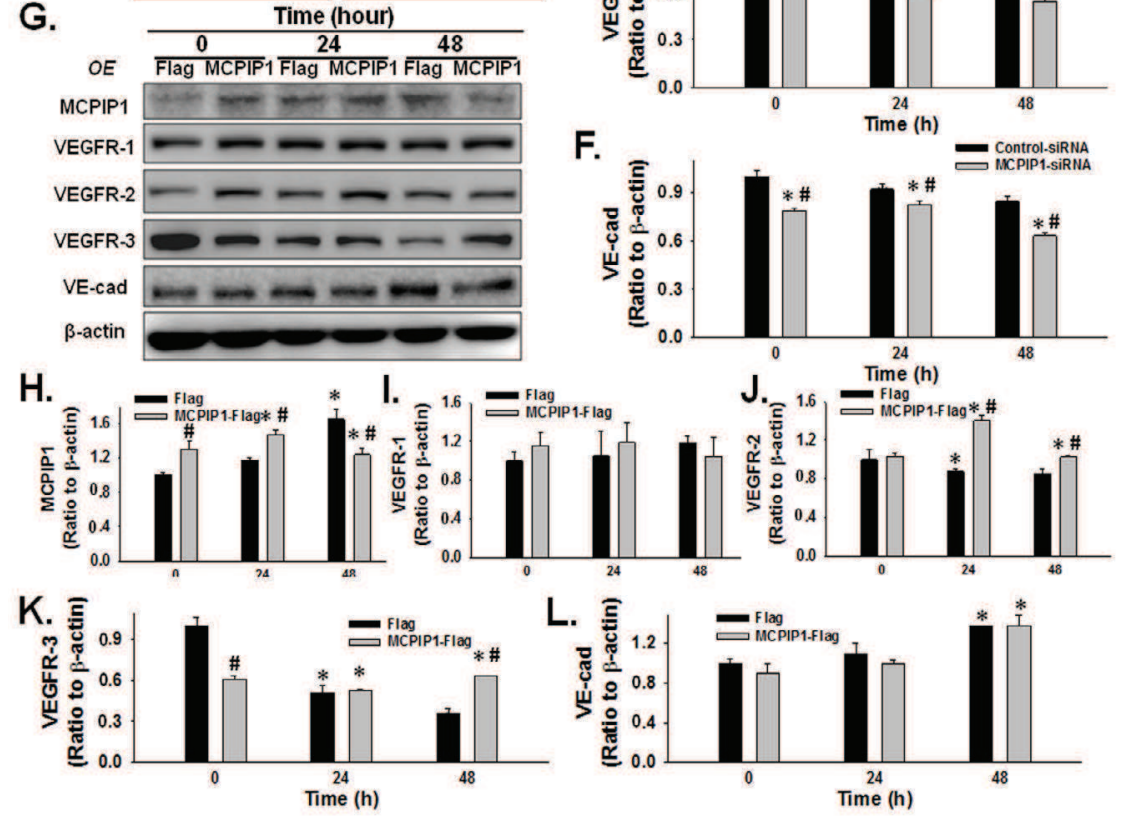

B.

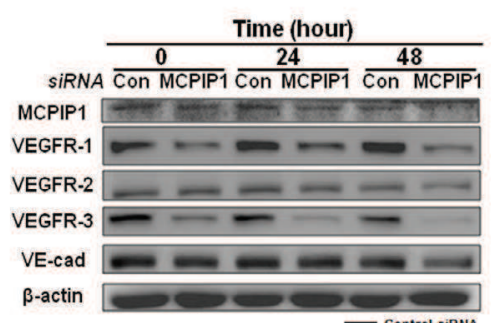

C.
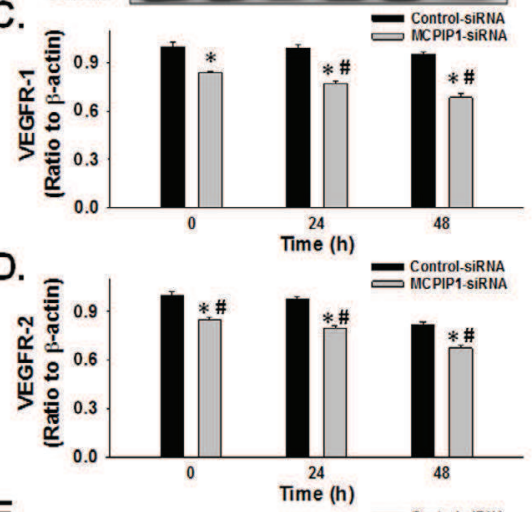

E.

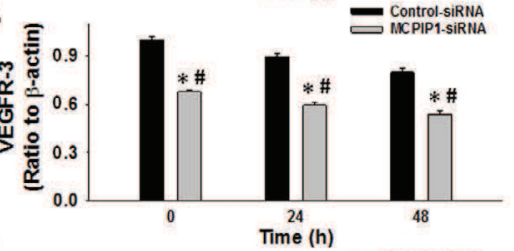

F.
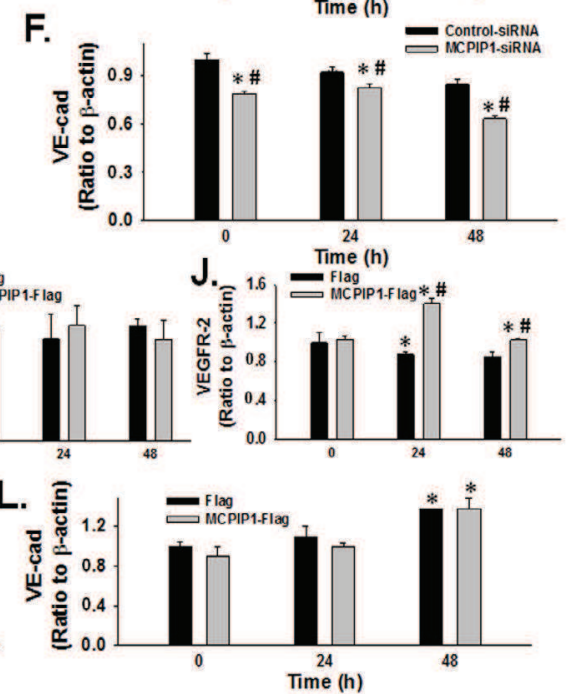

the $\mathrm{SiO}_{2}$ group at 0 hours. (G) Representative western blot showing the effects of transfecting HUVECs with MCPIP1-Flag on the $\mathrm{SiO}_{2}$-induced changes in the expression of VEGFR-1, VEGFR-2, VEGFR-3 and VE-cad. Densitometric analyses from five separate experiments showing the effect of transfection of HUVECs with MCPIP1-Flag (H) on the $\mathrm{SiO}_{2}$-induced changes in the expression of VEGFR-1 (I), VEGFR-2 (J), VEGFR-3 (K) and VE-cad (L). ${ }^{*} \mathrm{p}<0.05$ vs the control group at 0 hours; $\# \mathrm{p}<0.05$ vs the $\mathrm{SiO}_{2}$ group at 0 hours. 


\section{Cellular Physiology Cell Physiol Biochem 2016;40:309-325 \begin{tabular}{l|l} 
and Biochemistry Published online: November 21, 2016 & $\begin{array}{l}\text { ( ) 2016 The Author(s). Published by S. Karger AG, Basel } \\
\text { www.karger.com/cpb }\end{array}$ \\
\cline { 2 - 3 }
\end{tabular}

MCPIP1 in HUVECs using siRNA alleviated the increase in Col I, Col III and $\alpha$-SMA expression that was induced by $\mathrm{SiO}_{2}$ in the control cells (Fig. 2D-H). All of these data suggest that MCPIP1 plays a direct role in the acquisition of mesenchymal characteristics.

\section{Role of MCPIP1 in $\mathrm{SiO}_{2}$-induced loss of endothelial characteristics by HUVECs}

After exploring the role of MCPIP1 in the acquisition of a mesenchymal phenotype, we next sought to elucidate the function of MCPIP1 in another step of EndMT: loss of an endothelial phenotype. Therefore, we first measured the extent of co-localization between MCPIP1 and VEGFR-2 in HUVECs using immunocytochemical staining. As shown in Fig. 3A, exposure to $\mathrm{SiO}_{2}$ induced an increase in the expression of MCPIP1 and a decrease in the expression of VEGFR-2 in HUVECs. To further define the correlation between the changes in MCPIP1 and VEGFR-2 levels, MCPIP1 was specifically silenced in HUVECs using siRNA. Instead of inducing recovery of the expression of endothelial markers, down-regulation of MCPIP1 resulted in a stronger decrease in the expression of VEGFR2-3 and VE-cad than

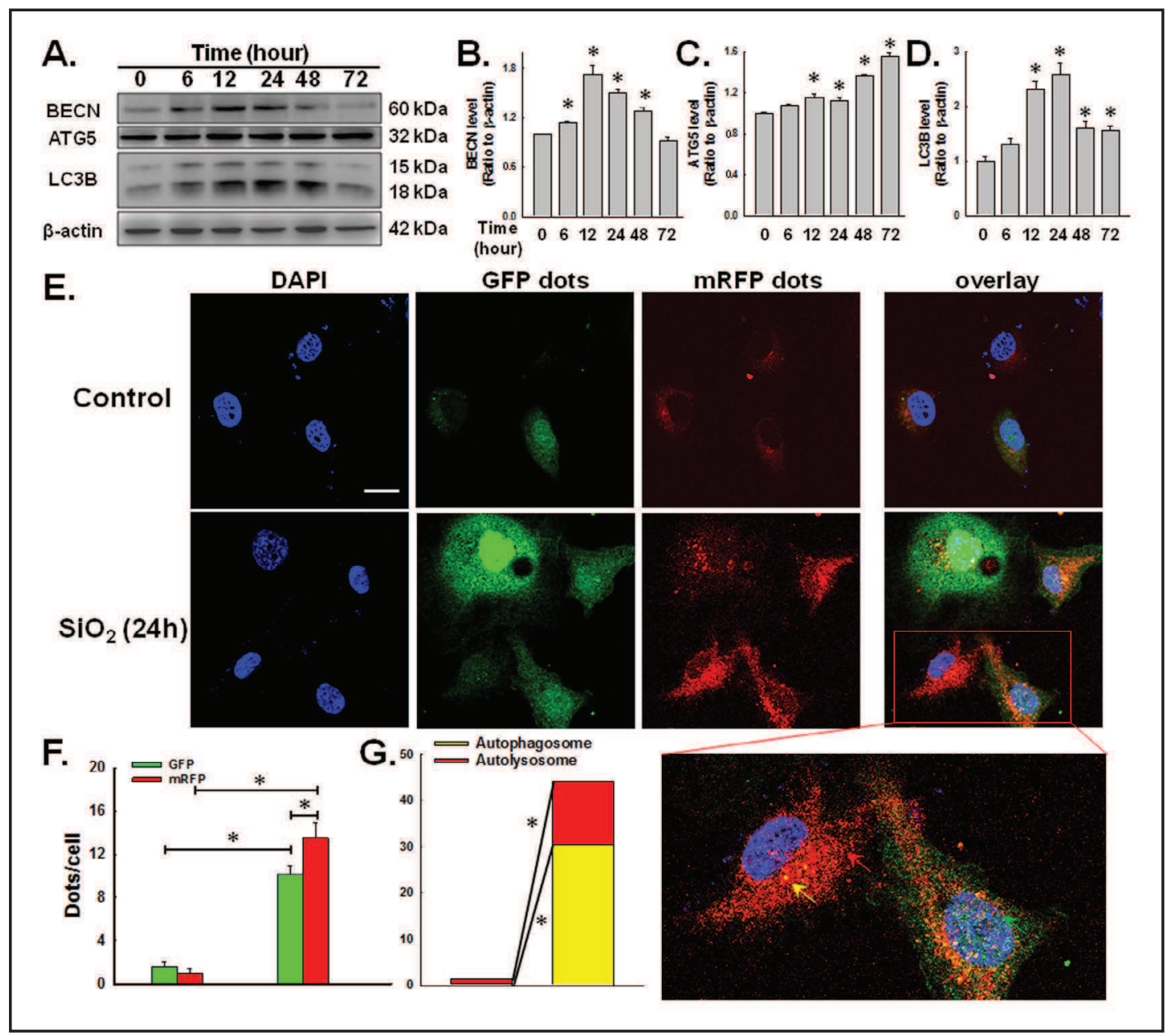

Fig. 4. The role of autophagy in the $\mathrm{SiO}_{2}$-induced loss of an endothelial phenotype by HUVECs. (A) Representative western blot showing the effects of $\mathrm{SiO}_{2}$ on the expression of the autophagy markers BECN, ATG5 and LC3B in HUVECs. The results of densitometric analyses from five separate experiments suggested that $\mathrm{SiO}_{2}$ induced the expression of BECN (B) ATG5 (C) and LC3B (D) in a time-dependent manner. ${ }^{*}$ p $<0.05$ vs the 0-hour group. (E) Representative images showing the effect of $\mathrm{SiO}_{2}$ on the appearance of RFP-GFP-MAP1LC3 puncta. Scale bar=10 $\mu \mathrm{m}$. (F) Quantification of RFP- and GFP-fluorescent puncta of RFP-GFP-MAP1LC3; the results demonstrated that $\mathrm{SiO}_{2}$ induced autophagy. ${ }^{*}<<0.05$ vs the control group. (G) Quantification of RFP-fluorescent puncta and both RFP- and GFP-fluorescent puncta of RFP-GFP-MAP1LC3; the results demonstrated that $\mathrm{SiO}_{2}$ induced autophagic flux. ${ }^{*} \mathrm{p}<0.05$ vs the control group. 


\section{Cellular Physiology Cell Physiol Biochem 2016;40:309-325 \begin{tabular}{ll|l|} 
and Biochemistry & Dublished online: November 21, 2016 & $\begin{array}{l}\text { @ 2016 The Author(s). Published by S. Karger AG, Basel } \\
\text { www.karger.com/cpb }\end{array}$ \\
\hline
\end{tabular} Chao et al.: MCPIP1 Promotes EndMT in Silicosis}

that induced by $\mathrm{SiO}_{2}$; furthermore VEGFR-1 expression was decreased only in the MCPIP1 siRNA-treated group (Fig. 3B-F). To validate this finding, we used a MCPIP1-Flag plasmid [29] to upregulate the expression of MCPIP1 in HUVECs. As shown in Fig. 3G-L, transfecting HUVECs with MCPIP1-Flag increased the expression of MCPIP1 within 24 hours, whereas the $\mathrm{SiO}_{2}$-induced decreases in VEGFR-2, VEGFR-3 and VE-cad were ameliorated. VEGFR-1 was not affected by transfection with MCPIP1-Flag, and these findings were consistent with the results shown in Fig. 1. These data indicated that the mechanism responsible for the loss of endothelial characteristics was different from the mechanisms responsible for the acquisition of a mesenchymal phenotype.

\section{$\mathrm{SiO}_{2}$ induced autophagy in HUVECS}

Previous data suggested that MCPIP1-induced autophagy plays a role in the functions of adipogenesis [23]. It appeared relevant to determine whether autophagy occurred in HUVECs following exposure to $\mathrm{SiO}_{2}$ since cell proliferation is an important aspect of silicosis. As shown in Fig. 4A-D, exposing HUVECs to $\mathrm{SiO}_{2}$ significantly up-regulated the expression of the autophagy markers BECN, ATG5 and LC3B (according to the guidelines on the evaluation of autophagy [31]) in a time-dependent manner. Autophagic flux was also monitored in HUVECs that were transduced with adenovirus carrying dually fluorescent mRFP-GFPMAP1LC3, which expresses MAP1LC3, a specific marker of autophagosome formation [23]. Differences in the nature of how GFP and RFP fluorescence is induced under acidic conditions were used to determine the results of these experiments [27]. GFP fluorescence is sensitive to the acidic conditions within the lysosomal lumen, whereas RFP fluorescence is relatively

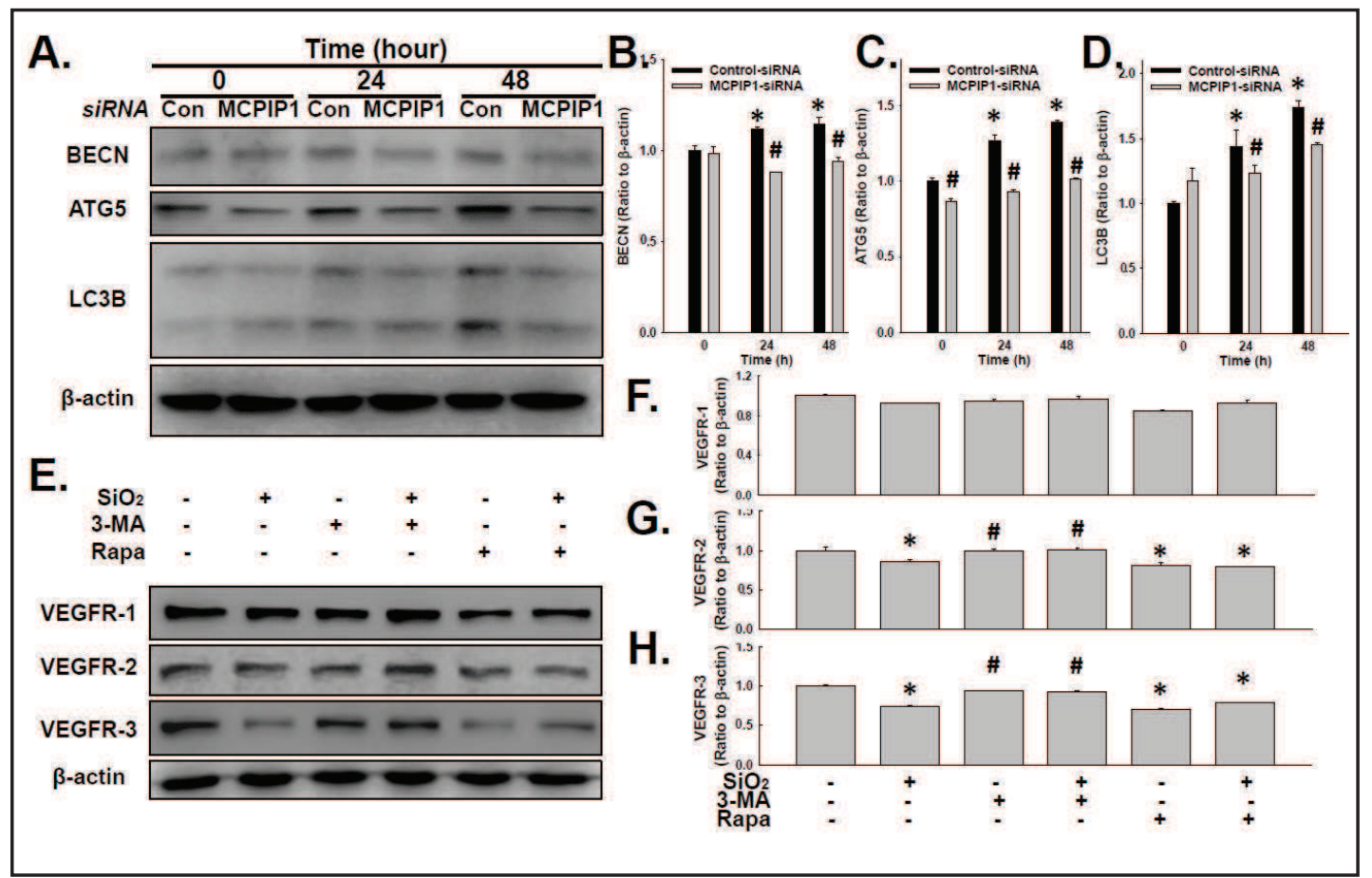

Fig. 5. Role of MCPIP1 in the $\mathrm{SiO}_{2}$-induced loss of an endothelial phenotype by HUVECs. (A) Representative western blot showing the effects of RNAi targeting MCPIP1 on $\mathrm{SiO}_{2}$-induced BECN, ATG5 and LC3B expression in HUVECs. Densitometric analyses from five separate experiments suggesting that RNAi targeting MCPIP1 attenuated the $\mathrm{SiO}_{2}$-induced expression of BECN (B), ATG5 (C) and LC3B (D). * $\mathrm{p}<0.05$ vs the control group at 0 hours; $\#$ p $<0.05$ vs the control group at the corresponding time point. (E) Representative western blots demonstrating the effects of 3-MA and Rapa application on the $\mathrm{SiO}_{2}$-induced changes in the expression of VEGFR-1, VEGFR-2 and VEGFR-3. Densitometric analyses from five separate experiments showing the effects of 3-MA and Rapa on the $\mathrm{SiO}_{2}$-induced changes in the expression of VEGFR-1 (F), VEGFR-2 (G) and VEGFR-3 (H) in HUVECs. * p $<0.05$ vs the control group; \# $\mathrm{p}<0.05$ vs the $\mathrm{SiO}_{2}$ group. 


\section{Cellular Physiology Cell Physiol Biochem 2016;40:309-325 \begin{tabular}{ll|l} 
DOI: 10.1159/000452547 & O 2016 The Author(s). Published by S. Karger AG, Basel \\
www.karger.com/cpb
\end{tabular}

stable under acidic conditions. Thus, the colocalization of GFP and RFP signals (yellow dots) indicates the presence of phagophores or autophagosomes that have not fused with lysosomes, whereas RFP-only signals (red puncta) indicate autolysosomes [23]. As shown in Fig. 4E-G, $\mathrm{SiO}_{2}$ induced a significant increase in the number of yellow dots (Fig. 4G) and concomitantly enhanced the increase in RFP-only MAP1LC3-positive dots in the HUVECs of the $\mathrm{SiO}_{2}$-treated group (Fig. 4F, G), indicating that $\mathrm{SiO}_{2}$ induced autophagic flux.

Autophagy mediated by MCPIP1 promoted the $\mathrm{SiO}_{2}$-induced loss of an endothelial phenotype by HUVECS

To further elucidate whether autophagy mediates the MCPIP1-induced loss of an endothelial phenotype by HUVECs, we used MCPIP1 siRNA to explore the relationship

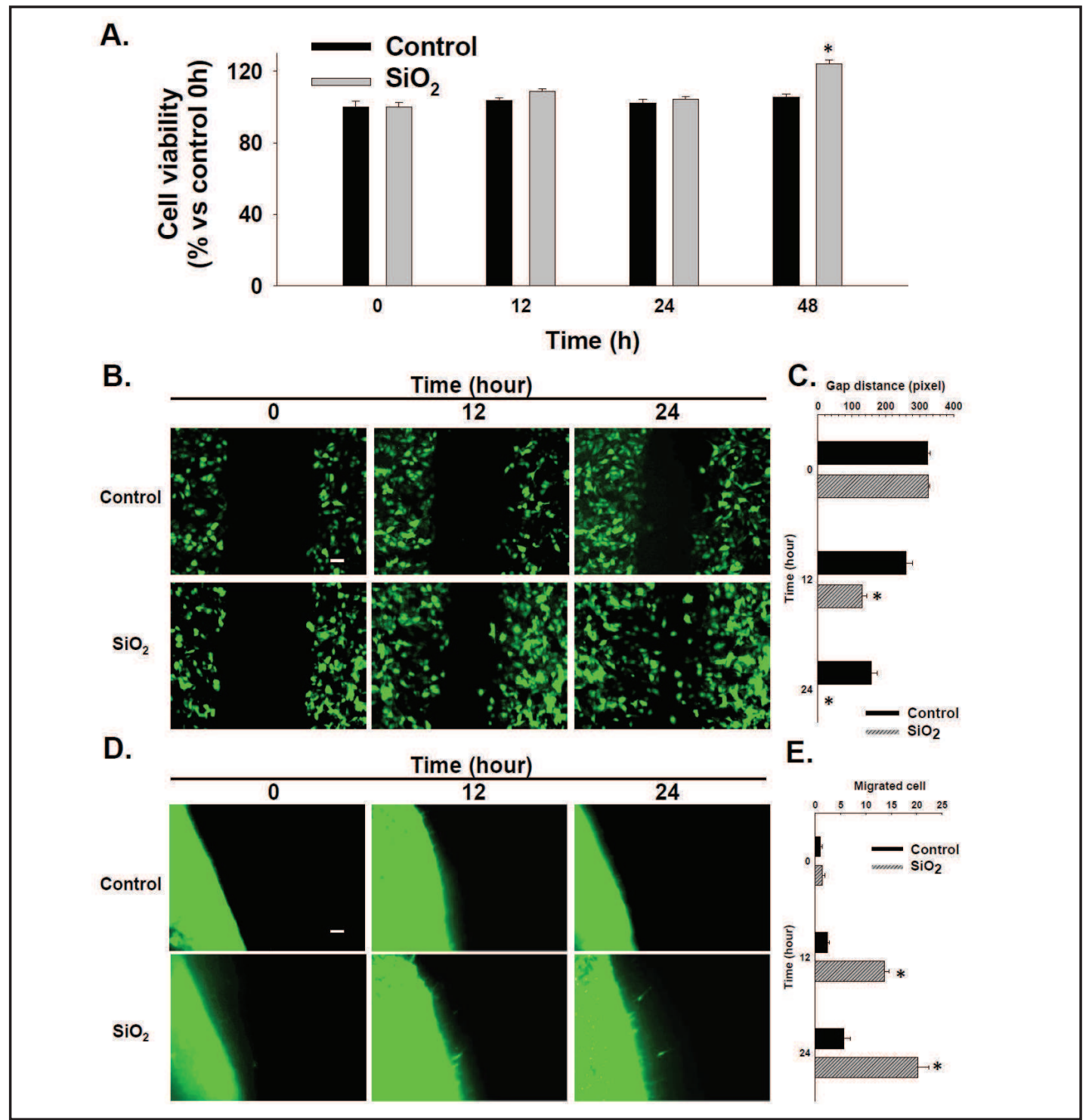

Fig. 6. $\mathrm{SiO}_{2}$ induced functional changes in HUVECs. (A) MTT assay showing that the $\mathrm{SiO}_{2}$-induced increase in cell viability was time-dependent in HUVECs. ${ }^{*} \mathrm{p}<0.05$ vs the 0 -hour group. (B) Representative images showing the effects of $\mathrm{SiO}_{2}$ on GFP-labeled HUVEC migration in scratch assays. Scale bar=80 $\mu \mathrm{m}$. (C) Quantification of the scratch gap distances from six separate experiments. $* p<0.05$ vs the control group at the corresponding time point. (D) Representative images showing the effects of $\mathrm{SiO}_{2}$ on GFP-labeled HUVEC migration in a nested matrix. Scale bar $=80 \mu \mathrm{m}$. (E) Quantification of cell migration from six separate experiments. ${ }^{*} \mathrm{p}<0.05$ vs the control group at the corresponding time point. 


\section{Cellular Physiology Cell Physiol Biochem 2016;40:309-325 \begin{tabular}{ll|l} 
DOI: 10.1159/000452547 21,2016 & $\begin{array}{l}\text { O) } 2016 \text { The Author(s). Published by S. Karger AG, Basel } \\
\text { www.karger.com/cpb }\end{array}$
\end{tabular}

between MCPIP1 and autophagy. As shown in Fig. 5A-D, silencing MCPIP1 in HUVECs significantly inhibited the $\mathrm{SiO}_{2}$-induced increase in the expression of BECN, ATG5 and LC3B.

After we determined that MCPIP1 mediated $\mathrm{SiO}_{2}$-induced autophagy in HUVECs, a specific inhibitor of autophagy, 3-methyladenine (3-MA, $1 \mathrm{mmol} / \mathrm{L}$ ), and a specific activator of autophagy, rapamycin (Rapa, $1 \mu \mathrm{mol} / \mathrm{L}$ ), were applied to the cells. [32] As shown in Fig. $5 \mathrm{E}-\mathrm{H}$, pretreatment with 3-MA for 1 hour attenuated the $\mathrm{SiO}_{2}$-induced decreases in VEGFR-2 and VEGFR-3 levels observed in the control HUVECs. However, pretreatment with Rapa for 1 hour did not further decrease the expression of VEGFR-2 and VEGFR-3 beyond that induced by $\mathrm{SiO}_{2}$. This result may be because $\mathrm{SiO}_{2}$ treatment exerted a maximal effect. These data suggest that autophagy induced the loss of an endothelial phenotype by HUVECs upon exposure to $\mathrm{SiO}_{2}$.

Fig. 7. Pyk2 and MLC-2 mediated the effect of MCPIP1 on $\mathrm{SiO}_{2}$-induced HUVEC migration. (A) Representative images showing the effects of RNAi targeting MCPIP1 on the $\mathrm{SiO}_{2}$-induced migration of GFP-labeled HUVECs in scratch assays. Scale bar $=80 \mu \mathrm{m}$. (B) Quantification of the scratch gap distances in six separate experiments. ${ }^{*} \mathrm{p}<0.05$ vs the control group at the corresponding time point. (C) MTT assay showing that RNAi targeting MCPIP1 attenuated the $\mathrm{SiO}_{2}$-induced increase in HUVEC viability. * $\mathrm{p}<0.05$ vs the control group at the corresponding time point. (D) Representative western blot showing the effects of $\mathrm{SiO}_{2}$ on the phosphorylation of Pyk2 and MLC-2 in HUVECs. Densitometric analyses from five separate experiments suggested that $\mathrm{SiO}_{2}$ induced the phosphorylation of Pyk2 (E) and MLC-2 (F) in HUVECs. ${ }^{*} \mathrm{p}<0.05$ vs the 0-hour group. (G) Representative western

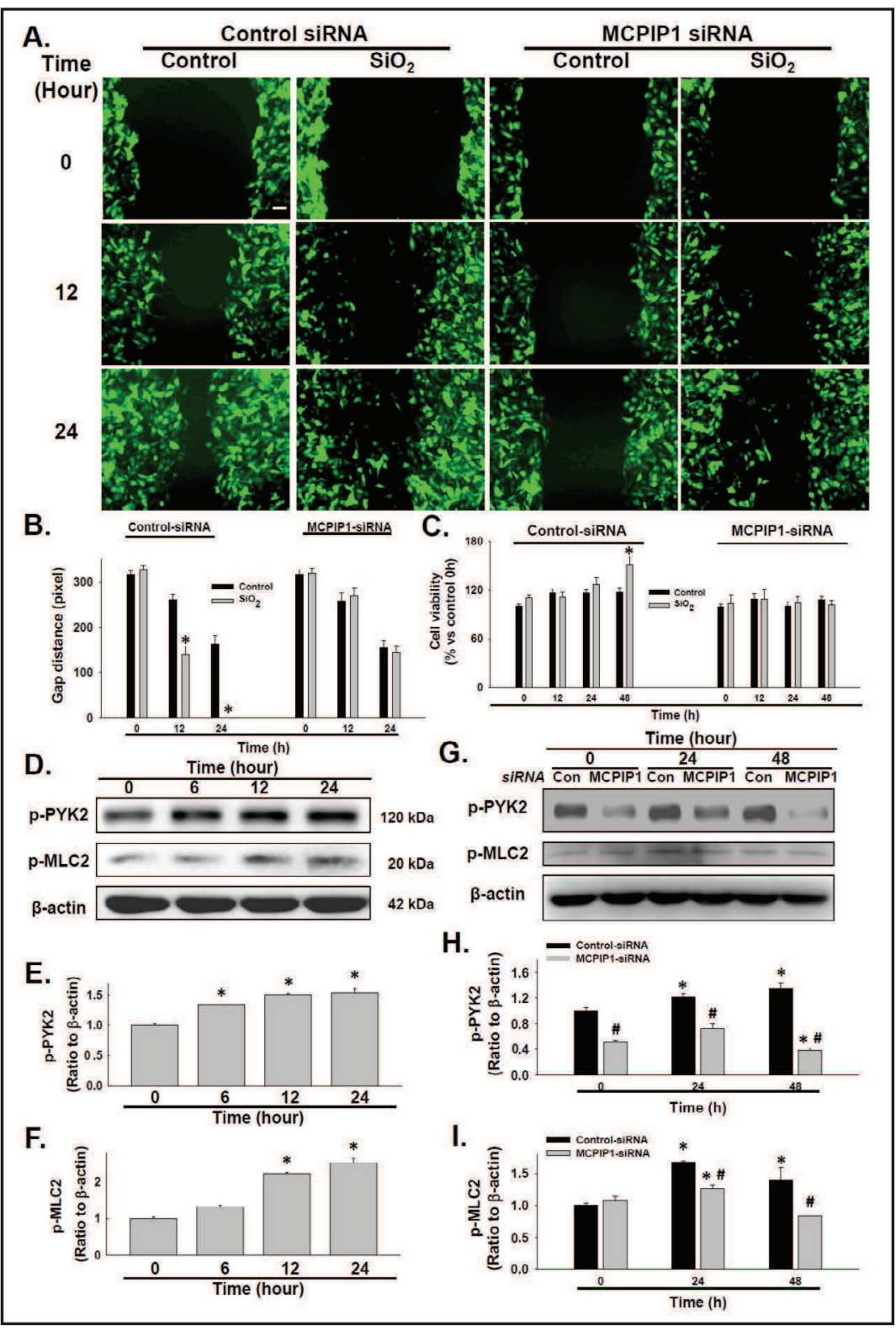

blot showing the effects of RNAi targeting MCPIP1 on the $\mathrm{SiO}_{2}$-induced phosphorylation of Pyk2 and MLC-2 in HUVECs. Densitometric analyses from five separate experiments suggested that RNAi targeting MCPIP1 attenuated the $\mathrm{SiO}_{2}$-induced phosphorylation of Pyk2 (H) and MLC-2 (I) in HUVECs. ${ }^{*} \mathrm{p}<0.05$ vs the control group at 0 hours; \# $\mathrm{p}<0.05$ vs the control group at the corresponding time point. 


\section{Cellular Physiology Cell Physiol Biochem 2016;40:309-325

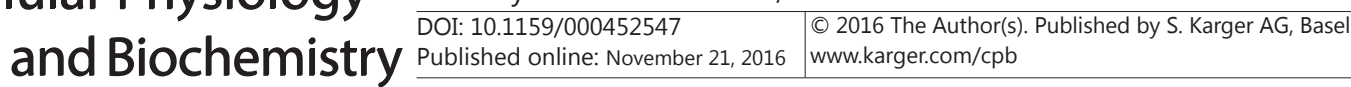 Chao et al.: MCPIP1 Promotes EndMT in Silicosis}

Fig. 8. $\mathrm{SiO}_{2}$ induced the phosphorylation of MAPK and PI3K/Akt in HUVECs. (A) Representative western blot showing that $\mathrm{SiO}_{2}$ induced the phosphorylation of Akt, p38, JNK and ERK in HUVECs. Densitometric analyses of the expression of p-Akt (B), p-p38 (C), p-JNK (D) and p-ERK (E) from five separate experiments. * $\mathrm{p}<0.05$ vs the 0 -min group. (F) Representative western blot showing that MCPIP1, Col I, Col III and $\alpha$-SMA expression was attenuated by pretreating HUVECs with a MAPK or PI3K/Akt inhibitor. Densitometric analyses of MCPIP1 (G), Col I (H), Col III (I) and $\alpha$-SMA expression (J) from five separate experiments. * $\mathrm{p}<0.05$ vs the control group; \# $\mathrm{p}<0.05$ vs the $\mathrm{SiO}_{2}$ group.

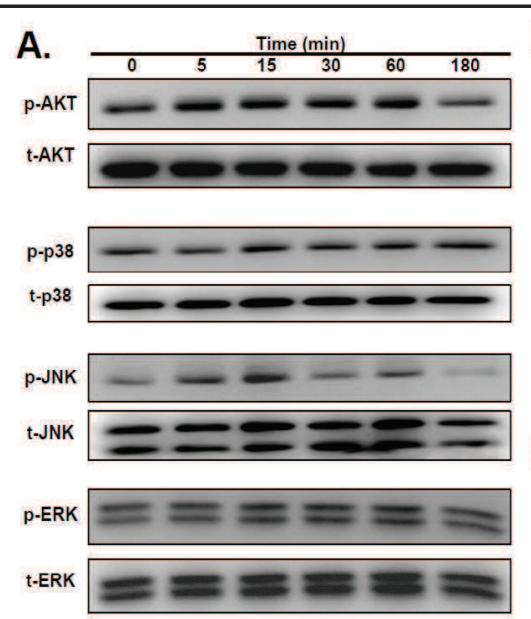

B.

C.
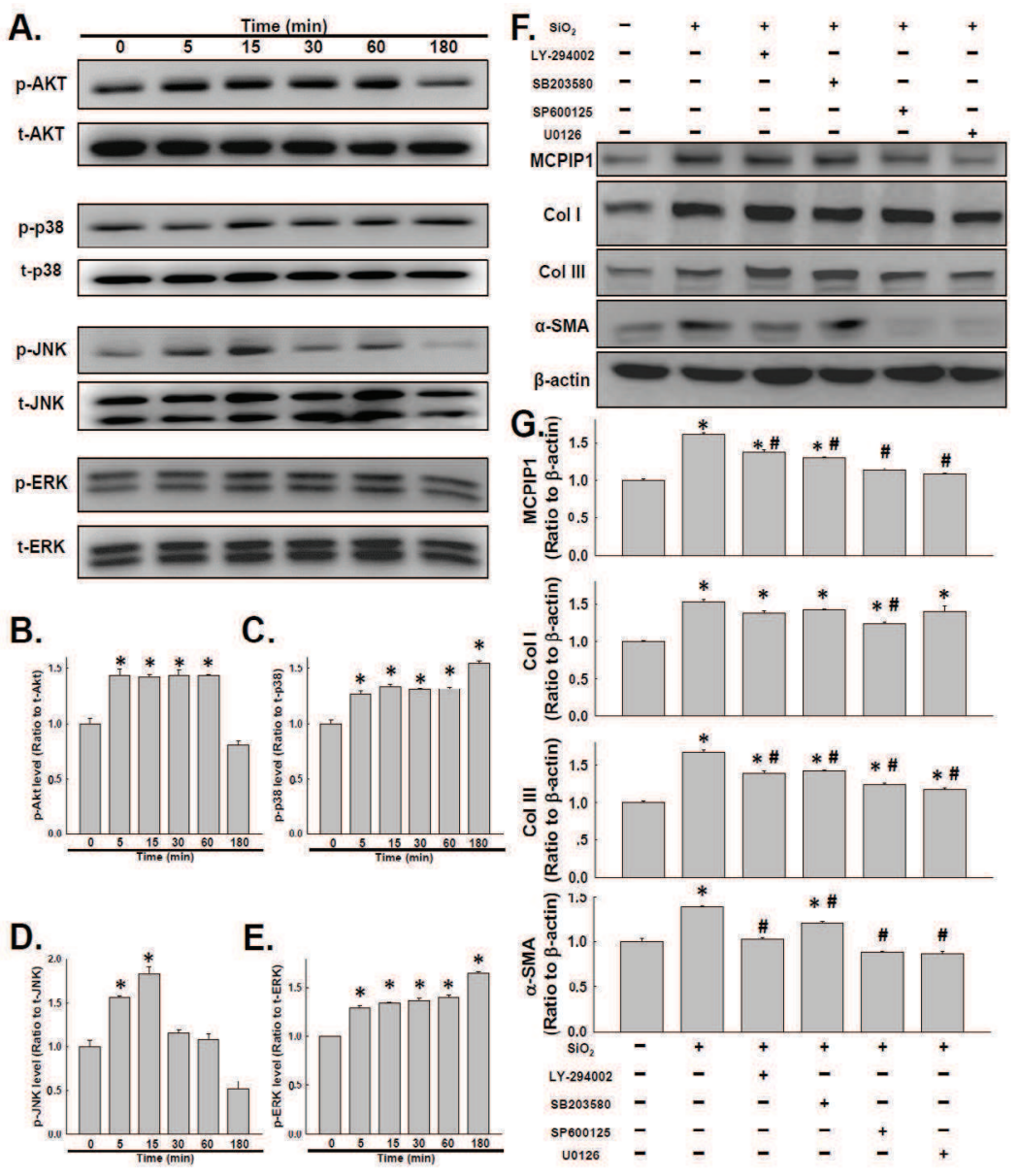

E.

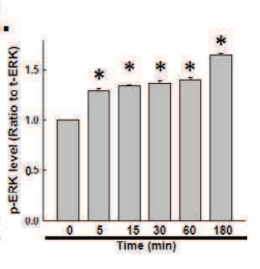

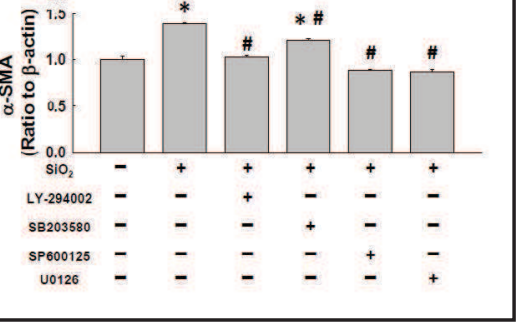

\section{$\mathrm{SiO}_{2}$ induced functional changes in HUVECS}

Accumulating evidence indicates that the onset of pulmonary fibrosis is accompanied by changes in cell proliferation and migration [33-36]. To further understand the functional effects of endothelial marker loss and mesenchymal marker acquisition by these cells, HUVEC migration and viability were evaluated upon exposure to $\mathrm{SiO}_{2}$. As shown in Fig. 6A, 48 hours of exposure to $\mathrm{SiO}_{2}$ induced a significant increase in HUVEC viability. Moreover, the migratory ability of HUVECs began to increase after 12 hours of $\mathrm{SiO}_{2}$ exposure, and the gap distance in scratch assays reached 0 after 24 hours of exposure to $\mathrm{SiO}_{2}$ (Fig. 6B, C). However, this enhancement of cell migration did not result from an increase in cell abundance because cell viability was not changed at any time point up to 24 hours of $\mathrm{SiO}_{2}$ exposure (Fig. 6A). Increasing evidence suggests that there are significant discrepancies in cell behavior between 2D and 3D culture systems $[16,29,37]$ and that cell migration in a 3D matrix is a complicated process that involves cell-matrix adhesion, cell-matrix interactions, and global/ local matrix remodeling [38]. We therefore measured cell migration using a nested matrix model that better represented the microenvironment of living tissue [29]. As shown in Fig. $6 \mathrm{D}, \mathrm{E}, \mathrm{SiO}_{2}$ induced a similar effect on cell migration in the 3D model to the effect that we observed in the scratch assay. Taken together, $\mathrm{SiO}_{2}$ induced a rapid and sustained increase in HUVEC migration.

MCPIP1 mediated the effect of $\mathrm{SiO}_{2}$ on HUVEC migration and population abundance

After demonstrating that endothelial cells undergoing EndMT acquire mesenchymal properties and increased migratory ability, which is a critical characteristic of pulmonary fibrosis, we explored whether MCPIP1 mediated cell migration and proliferation. HUVECs 


\section{Cellular Physiology Cell Physiol Biochem 2016;40:309-325 \\ \begin{tabular}{ll|l|l} 
and Biochemistry & $\begin{array}{l}\text { DOI: 10.1159/000452547 } \\
\text { Published online: November 21, } 2016\end{array}$ & $\begin{array}{l}\text { ( ) 2016 The Author(s). Published by S. Karger AG, Basel } \\
\text { www.karger.com/cpb }\end{array}$ \\
\hline
\end{tabular} \\ Chao et al.: MCPIP1 Promotes EndMT in Silicosis}

treated with $\mathrm{SiO}_{2}$ showed a significant increase in migration on scratch assays, while silencing MCPIP1 in HUVECs attenuated the $\mathrm{SiO}_{2}$-induced increase in cell migration (Fig. $7 \mathrm{~A}, \mathrm{~B}$ ). Furthermore, specifically silencing MCPIP1 in HUVECs abolished the $\mathrm{SiO}_{2}$-induced increase in cell viability (Fig. 7C). To further explore the mechanism underlying the observed increase in the migration of HUVECs undergoing EndMT, markers that are relevant to cell migration, such as protein-rich tyrosine kinase 2 (Pyk2) and myosin light-chain 2 (MLC2), were examined via western blot analysis. As shown in Fig. 7D-F, $\mathrm{SiO}_{2}$ induced rapid and sustained phosphorylation of Pyk2 and MLC-2, and the phosphorylation of both factors were attenuated when MCPIP1 siRNA was applied to HUVECs (Fig. 7G-I).

Involvement of MAPKs and the PI3K/Akt pathway in $\mathrm{SiO}_{2}$-induced EndMT in HUVECs

To improve our understanding of the molecular mechanism underlying $\mathrm{SiO}_{2}$-induced EndMT, we investigated the potential association between kinase activation and EndMT by measuring the phosphorylation of MAPKs and PI3K/Akt over $3 \mathrm{~h}$ of exposure to $\mathrm{SiO}_{2}$. As shown in Fig. 8A-E, within 5 min of $\mathrm{SiO}_{2}$ exposure, Akt, p38, JNK and Erk underwent phosphorylation. While the phosphorylation of Akt, p38 and Erk persisted up to 3 hours, $\mathrm{SiO}_{2}$ induced only rapid and transient phosphorylation of JNK.

After confirming that MAPK and PI3K/Akt activities were enhanced after exposure to $\mathrm{SiO}_{2}$, pharmacological inhibitors of MAPK and PI3K/Akt was applied to determine whether these pathways are involved in EndMT in HUVECs that were exposed to $\mathrm{SiO}_{2}$. As shown in Fig. 8F-J, pretreating the HUVECs with the commercially available small molecules LY-294002 (an Akt inhibitor, $25 \mu \mathrm{mol} / \mathrm{L}$ ), SB203580 (a p38 inhibitor, $10 \mu \mathrm{mol} / \mathrm{L}$ ), SP600125 (a JNK inhibitor, $20 \mu \mathrm{mol} / \mathrm{L}$ ) or U0126 (a MEK inhibitor, $25 \mu \mathrm{mol} / \mathrm{L}$ ) attenuated the $\mathrm{SiO}_{2}$-induced up-regulation of MCPIP1, Col I, Col III and $\alpha$-SMA.

\section{Discussion}

Silicosis, an occupational disease caused by inhaling silica, is characterized by progressive pulmonary fibrotic reactions $[1,2,39,40]$. Although EndMT has been shown to play a role in fibrosis in various settings $[7,8]$, the role of EndMT in pulmonary fibrosis induced by $\mathrm{SiO}_{2}$ were unclear. Our findings suggest that MCPIP1 is involved in the process of EndMT.

Inhaled $\mathrm{SiO}_{2}$ is not effectively eliminated from the body [2]. $\mathrm{SiO}_{2}$ destroys the barrier between the air and blood, which exposes endothelial cells to silica. [41] These breaks in the air-blood barrier result in the formation of deposits of $\mathrm{SiO}_{2}$ in organs such as the liver, kidneys, spleen, heart, and abdominal lymph nodes [42-48]. Moreover, stimuli such as bleomycin not only induced the activation of endothelial cells but also caused endothelial cells to undergo EndMT, exacerbating endothelial cell dysfunction [8]. We therefore hypothesized that endothelial cells stimulated with silica may undergo EndMT.

EndMT is first observed during embryonic development in the heart $[49,50]$. During the course of physiological and pathological processes, EndMT results in the loss of an endothelial phenotype and the acquisition of a mesenchymal phenotype. Each step of EndMT is characterized by changes in the levels of different sets of specific markers in addition to changes in the functions of the cell, including proliferation and migration [14]. In the current study, HUVECs exposed to $\mathrm{SiO}_{2}$ underwent EndMT, as indicated by a decrease in expression of endothelial cell-specific markers and an increase in expression of mesenchymal cell products (Fig. 1). Interestingly, $\mathrm{SiO}_{2}$ did not change the expression of VEGFR1 in HUVECs. The results of studies published to date indicate that VEGFR1 might act as a silent receptor for VEGF because it transmits a weak growth signal. Moreover, VEGFR1 might inhibit most of the effects of VEGF/VEGFR2 signaling in endothelial cells [51, 52]. VEGFR1 knockout mice die as a result of deficiencies in the structural organization of vessel walls, demonstrating that VEGFR1 plays an important role in embryonic vascularization [53]. Recent studies have suggested that the critical role of VEGFR1 in endothelial cells is not the regulation of angiogenesis but rather the induction of the paracrine release of tissue-specific 


\section{Cellular Physiology Cell Physiol Biochem 2016;40:309-325

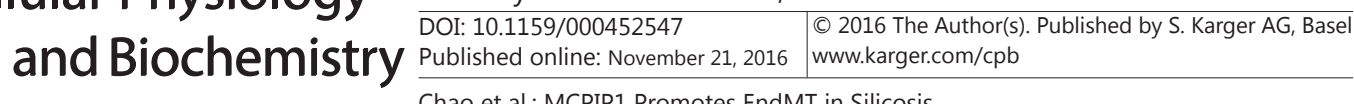

Fig. 9. Schematic showing the role of MCPIP1-mediated autophagy in $\mathrm{SiO}_{2}$-initiated fibrosis.

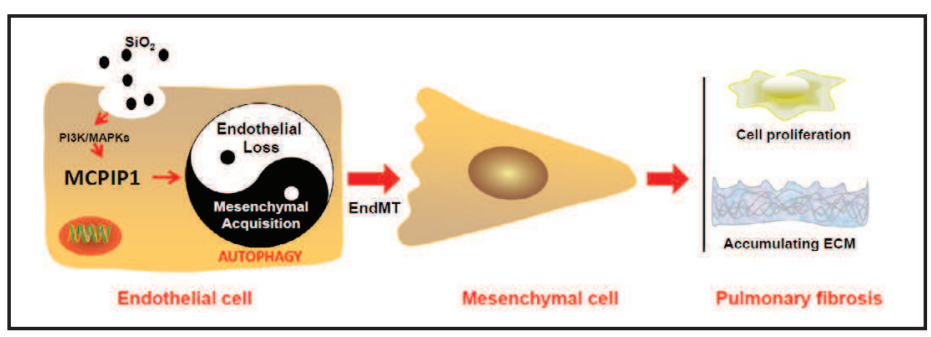

growth factors [54]. In contrast to VEGFR1, VEGFR2 plays a pivotal role in endothelial cell proliferation, NO and prostacyclin production, angiogenesis, and vascular permeability [5557] showed that activating VEGFR2 in HUVECs inhibited apoptosis. Hence, the silica-induced change in VEGFR2 expression in HUVECs is more meaningful than the silica-induced change in VEGFR1 expression.

Many factors can induce the EndMT process. During EndMT, the most important factor is transforming growth factor- $\beta$ (TGF- $\beta$ ), which promotes EndMT through the Smad $2 / 3$ and Smad1/5/8 signaling pathways [15]. In addition to the classical TGF- $\beta$ signaling pathways, other factors such as Notch, Wnt and miR-21 are also involved in EndMT processes [58, 59]. Not only traditional cytokines, but also chemokines have attracted more attention for their roles in EndMT. Chemokine (C-C motif) ligand 2 (CCL2) can orchestrate the migration of monocytes across the endothelium of blood vessels to induce a late fibrogenic reaction [60, 61]. CCR2, which is the receptor of CCL2, is expressed on endothelial cells [62]. MCPIP1 is a novel CCCH zinc-finger-containing protein that is significantly induced by CCL2 in human peripheral blood monocytes [63]. Previous data from our lab suggest that MCPIP1 plays a role in HUVEC migration and proliferation in the context of ischemia and reperfusion [23]. Other studies have suggested that MCPIP1 is also involved in enhancing angiogenic activity, and specifically silencing MCPIP1 resulted in the suppression of VEGFR in HUVECs, suggesting a positive correlation between MCPIP1 and VEGFR expression [21]. We propose that MCPIP1 may be involved in $\mathrm{SiO}_{2}$-induced EndMT. In accordance with this hypothesis, MCPIP1 was found to be involved in the $\mathrm{SiO}_{2}$-induced acquisition of a mesenchymal phenotype.

To our surprise, although we observed a negative correlation between MCPIP1 and VEGFR expression upon $\mathrm{SiO}_{2}$ exposure, specifically silencing MCPIP1 further decreased VEGFR expression instead of rescuing its expression. In fact, our and other laboratories have shown that MCPIP1 promotes angiogenesis via its RNase activity, suppressing the production of the antiangiogenic microRNA (miR)-20b and miR-34a $[21,64]$, which are thought to sustain endothelial cell properties. Our findings suggest that $\mathrm{SiO}_{2}$ induces HUVECs to lose of their endothelial phenotype rather than undergo angiogenesis, indicating that different mechanisms may be involved in the loss of an endothelial phenotype and the acquisition of a mesenchymal phenotype. Endothelial cells first lose their endothelial characteristics as a result of adaptation to an environment that is changed by catabolic and anabolic processes that are collectively referred to as autophagy. MCPIP1 has been found to induce autophagy [65] and differentiation [66] through its transcription factor activity, RNase activity, and deubiquitinase activity, consistent with our findings. However, the detailed mechanism by which MCPIP1 participates in the loss of an endothelial phenotype must be further explored.

EndMT by endothelial cells leads to microvascular deficiency and endothelial dysfunction, which contribute to cardiac fibrosis [12]. In the current study, MCPIP1 mediated the proliferation and migration of HUVECs, indicating dysfunction of these endothelial cells. Morphometric studies of idiopathic pulmonary fibrosis (IPF) showed that capillary density was decreased in the fibrotic region [67].

In conclusion, MCPIP1 appeared to participate in the induction of EndMT in endothelial cells that were exposed to $\mathrm{SiO}_{2}$ via a pathway that appeared to involve autophagy, MAPKs and Akt. These processes subsequently led to increased cellular viability and migration. Our results suggest that MCPIP1-induced EndMT in endothelial cells plays an important role in the development of silicosis. Targeting the MCPIP1/autophagy signaling axis may represent a therapeutic strategy for preventing silicosis (Fig. 9). 


\section{Cellular Physiology Cell Physiol Biochem 2016;40:309-325 \begin{tabular}{ll|l} 
and Biochemistry & Dublished online: November 21, 2016 & $\begin{array}{l}\text { @ 2016 The Author(s). Published by S. Karger AG, Basel } \\
\text { www.karger.com/cpb }\end{array}$ \\
\hline
\end{tabular} Chao et al.: MCPIP1 Promotes EndMT in Silicosis}

\section{Acknowledgements}

This study is the result of work that was partially supported by the resources and facilities at the core laoratory of the Medical School of Southeast University. The National Natural Science Foundation of China (No. 81473263, 81400300, 81600045 and 81301870) and the Natural Science Foundation of Jiangsu Province, China (No. BK20141347 and BK20130642).

\section{Disclosure Statement}

The authors have no conflicts of interest to declare.

\section{References}

1 Piguet PF, Collart MA, Grau GE, Sappino AP, Vassalli P: Requirement of tumour necrosis factor for development of silica-induced pulmonary fibrosis. Nature 1990;344:245-247.

2 Leung CC, Yu IT, Chen W: Silicosis. Lancet 2012;379:2008-2018.

3 Badr G, Sayed D, Maximous D, Mohamed AO, Gul M: Increased susceptibility to apoptosis and growth arrest of human breast cancer cells treated by a snake venom-loaded silica nanoparticles. Cell Physiol Biochem 2014;34:1640-1651.

4 Nemmar A, Beegam S, Yuvaraju P, Yasin J, Shahin A, Ali BH: Interaction of amorphous silica nanoparticles with erythrocytes in vitro: Role of oxidative stress. Cell Physiol Biochem 2014;34:255-265.

5 Gerriets JE, Reiser KM, Last JA: Lung collagen cross-links in rats with experimentally induced pulmonary fibrosis. Biochim Biophys Acta 1996;1316:121-131.

6 Bujak M, Ren G, Kweon HJ, Dobaczewski M, Reddy A, Taffet G, Wang XF, Frangogiannis NG: Essential role of smad3 in infarct healing and in the pathogenesis of cardiac remodeling. Circulation 2007;116:2127-2138.

7 Arciniegas E, Neves CY, Carrillo LM, Zambrano EA, Ramirez R: Endothelial-mesenchymal transition occurs during embryonic pulmonary artery development. Endothelium-J Endoth 2005;12:193-200.

8 Hashimoto N, Phan SH, Imaizumi K, Matsuo M, Nakashima H, Kawabe T, Shimokata K, Hasegawa Y: Endothelial-mesenchymal transition in bleomycin-induced pulmonary fibrosis. Am J Respir Cell Mol Biol 2010;43:161-172.

9 Chen X, Cai J, Zhou X, Chen L, Gong Y, Gao Z, Zhang H, Huang W, Zhou H: Protective effect of spironolactone on endothelial-to-mesenchymal transition in huvecs via notch pathway. Cell Physiol Biochem 2015;36:191200.

10 Zhang Z, Zhang T, Zhou Y, Wei X, Zhu J, Zhang J, Wang C: Activated phosphatidylinositol 3-kinase/akt inhibits the transition of endothelial progenitor cells to mesenchymal cells by regulating the forkhead box subgroup o-3a signaling. Cell Physiol Biochem 2015;35:1643-1653.

11 Zeisberg EM, Potenta SE, Sugimoto H, Zeisberg M, Kalluri R: Fibroblasts in kidney fibrosis emerge via endothelial-to-mesenchymal transition. J Am Soc Nephrol 2008;19:2282-2287.

12 Zeisberg EM, Tarnavski O, Zeisberg M, Dorfman AL, McMullen JR, Gustafsson E, Chandraker A, Yuan X, Pu WT, Roberts AB, Neilson EG, Sayegh MH, Izumo S, Kalluri R: Endothelial-to-mesenchymal transition contributes to cardiac fibrosis. Nat Med 2007;13:952-961.

13 Widyantoro B, Emoto N, Nakayama K, Anggrahini DW, Adiarto S, Iwasa N, Yagi K, Miyagawa K, Rikitake Y, Suzuki T, Kisanuki YY, Yanagisawa M, Hirata K: Endothelial cell-derived endothelin-1 promotes cardiac fibrosis in diabetic hearts through stimulation of endothelial-to-mesenchymal transition. Circulation 2010;121:2407-2418.

14 Piera-Velazquez S, Li Z, Jimenez SA: Role of endothelial-mesenchymal transition (endomt) in the pathogenesis of fibrotic disorders. Am J Pathol 2011;179:1074-1080.

15 van Meeteren LA, ten Dijke P: Regulation of endothelial cell plasticity by tgf-beta. Cell Tissue Res 2012;347:177-186.

16 Liu H, Dai X, Cheng Y, Fang S, Zhang Y, Wang X, Zhang W, Liao H, Yao H, Chao J: Mcpip1 mediates silica-induced cell migration in human pulmonary fibroblasts. Am J Physiol Lung Cell Mol Physiol 2016;310:L121-132.

17 Liu X, Fang S, Liu H, Wang X, Dai X, Yin Q Yun T, Wang W, Zhang Y, Liao H, Zhang W, Yao H, Chao J: Role of human pulmonary fibroblast-derived mcp-1 in cell activation and migration in experimental silicosis. Toxicol Appl Pharmacol 2015;288:152-160. 


\section{Cellular Physiology Cell Physiol Biochem 2016;40:309-325 \begin{tabular}{ll|l} 
and Biochemistry & $\begin{array}{l}\text { DOI: 10.1159/000452547 } \\
\text { Published online: November 21, } 2016\end{array}$ & $\begin{array}{l}\text { ( ) 2016 The Author(s). Published by S. Karger AG, Basel } \\
\text { www.karger.com/cpb }\end{array}$ \\
\hline
\end{tabular} Chao et al.: MCPIP1 Promotes EndMT in Silicosis}

18 Wang X, Zhang Y, Zhang W, Liu H, Zhou Z, Dai X, Cheng Y, Fang S, Zhang Y, Yao H, Chao J: Mcpip1 regulates alveolar macrophage apoptosis and pulmonary fibroblast activation after in vitro exposure to silica. Toxicol Sci 2016;151:126-138.

19 Wang W, Liu H, Dai X, Fang S, Wang X, Zhang Y, Yao H, Zhang X, Chao J: P53/puma expression in human pulmonary fibroblasts mediates cell activation and migration in silicosis. Sci Rep 2015;5:16900.

20 Zhang W, Zhang M, Wang Z, Cheng Y, Liu H, Zhou Z, Han B, Chen B, Yao H, Chao J: Neogambogic acid prevents silica-induced fibrosis via inhibition of high-mobility group box 1 and mcp-1-induced protein 1 . Toxicol Appl Pharmacol 2016;309:129-140.

21 Niu J, Azfer A, Zhelyabovska O, Fatma S, Kolattukudy PE: Monocyte chemotactic protein (mcp)-1 promotes angiogenesis via a novel transcription factor, mcp-1-induced protein (mcpip). J Biol Chem 2008;283:14542-14551.

22 Labedz-Maslowska A, Lipert B, Berdecka D, Kedracka-Krok S, Jankowska U, Kamycka E, Sekula M, Madeja Z, Dawn B, Jura J, Zuba-Surma EK: Monocyte chemoattractant protein-induced protein 1 (mcpip1) enhances angiogenic and cardiomyogenic potential of murine bone marrow-derived mesenchymal stem cells. Plos One 2015;10:e0133746.

23 Zhu T, Yao Q Hu X, Chen C, Yao H, Chao J: The role of mcpip1 in ischemia/reperfusion injury-induced huvec migration and apoptosis. Cell Physiol Biochem 2015;37:577-591.

24 Yoon CM, Lee S, Hong SH, Jang J: Fabrication of density-controlled graphene oxide-coated mesoporous silica spheres and their electrorheological activity. J Colloid Interface Sci 2015;438:14-21.

25 Chao J, Pena T, Heimann DG, Hansen C, Doyle DA, Yanala UR, Guenther TM, Carlson MA: Expression of green fluorescent protein in human foreskin fibroblasts for use in $2 \mathrm{~d}$ and $3 \mathrm{~d}$ culture models. Wound Repair Regen 2014;22:134-140.

26 Carlson MA, Longaker MT, Thompson JS: Modulation of fak, akt, and p53 by stress release of the fibroblastpopulated collagen matrix. J Surg Res 2004;120:171-177.

27 Hariharan N, Zhai P, Sadoshima J: Oxidative stress stimulates autophagic flux during ischemia/reperfusion. Antioxid Redox Signal 2011;14:2179-2190.

28 Carlson MA, Prall AK, Gums JJ: Rna interference in human foreskin fibroblasts within the three-dimensional collagen matrix. Mol Cell Biochem 2007;306:123-132.

29 Chao J, Dai X, Pena T, Doyle DA, Guenther TM, Carlson MA: Mcpip1 regulates fibroblast migration in 3-d collagen matrices downstream of map kinases and nf-kappab. J Invest Dermatol 2015;135:2944-2954.

30 Grinnell F, Rocha LB, Iucu C, Rhee S, Jiang H: Nested collagen matrices: A new model to study migration of human fibroblast populations in three dimensions. Exp Cell Res 2006;312:86-94.

31 Klionsky DJ, Abdelmohsen K, Abe A, Abedin MJ, Abeliovich H, Acevedo Arozena A, Adachi H, Adams CM, Adams PD, Adeli K, Adhihetty PJ, Adler SG, Agam G, Agarwal R, et al.: Guidelines for the use and interpretation of assays for monitoring autophagy (3rd edition). Autophagy 2016;12:1-222.

32 Kim PK, Hailey DW, Mullen RT, Lippincott-Schwartz J: Ubiquitin signals autophagic degradation of cytosolic proteins and peroxisomes. Proc Natl Acad Sci USA 2008;105:20567-20574.

33 Madri JA, Furthmayr H: Collagen polymorphism in the lung. An immunochemical study of pulmonary fibrosis. Hum Pathol 1980;11:353-366.

34 Seyer JM, Hutcheson ET, Kang AH: Collagen polymorphism in idiopathic chronic pulmonary fibrosis. J Clin Invest 1976;57:1498-1507.

35 Fulmer JD, Bienkowski RS, Cowan MJ, Breul SD, Bradley KM, Ferrans VJ, Roberts WC, Crystal RG: Collagen concentration and rates of synthesis in idiopathic pulmonary fibrosis. Am Rev Respir Dis 1980;122:289301.

36 Bradley KH, Kawanami O, Ferrans VJ, Crystal RG: The fibroblast of human lung alveolar structures: A differentiated cell with a major role in lung structure and function. Methods Cell Biol 1980;21A:37-64.

37 Even-Ram S, Yamada KM: Cell migration in 3d matrix. Curr Opin Cell Biol 2005;17:524-532.

38 Rhee S, Grinnell F: Fibroblast mechanics in 3d collagen matrices. Adv Drug Deliv Rev 2007;59:1299-1305.

39 Moore BB, Peters-Golden M, Christensen PJ, Lama V, Kuziel WA, Paine R, 3rd, Toews GB: Alveolar epithelial cell inhibition of fibroblast proliferation is regulated by mcp-1/ccr2 and mediated by pge2. Am J Physiol Lung Cell Mol Physiol 2003;284:L342-349.

40 Rao KM, Porter DW, Meighan T, Castranova V: The sources of inflammatory mediators in the lung after silica exposure. Environ Health Perspect 2004;112:1679-1686.

41 Xu M, Qing M, Peng D: Silicon dioxide particles deposited in vessels and cartilage of the femoral head. Yonsei Med J 2014;55:1447-1449.

42 Ambrosi L: [histologic aspects of the kidney in silicosis]. Med Lav 1965;56:716-726.

43 Ambrosi L: [histologic aspects of the liver in silicosis patients]. Med Lav 1965;56:795-804. 


\section{Cellular Physiology Cell Physiol Biochem 2016;40:309-325 \begin{tabular}{ll|l} 
and Biochemistry & $\begin{array}{l}\text { DOI: 10.1159/000452547 } \\
\text { Published online: November 21, } 2016\end{array}$ & $\begin{array}{l}\text { ( ) 2016 The Author(s). Published by S. Karger AG, Basel } \\
\text { www.karger.com/cpb }\end{array}$ \\
\hline
\end{tabular} Chao et al.: MCPIP1 Promotes EndMT in Silicosis}

44 Ambrosi L: [histologic aspects of the spleen in silicosis patients]. Med Lav 1966;57:10-19.

45 Ambrosi L: [histological aspects of the heart in silicotic patients]. Med Lav 1966;57:104-110.

46 Carmichael GP, Jr., Targoff C, Pintar K, Lewin KJ: Hepatic silicosis. Am J Clin Pathol 1980;73:720-722.

47 Autio L, Turunen M, Lahtiharju A: Experimental silica cirrhosis in dog. Ann Med Exp Biol Fenn 1964;42:173-176.

48 Roperto F, Troncone A, Tranquillo A, Galati P: Extrapulmonary silicosis in two water buffaloes. J Comp Pathol 1995;112:97-103.

49 Armstrong EJ, Bischoff J: Heart valve development: Endothelial cell signaling and differentiation. Circ Res 2004;95:459-470.

50 Mercado-Pimentel ME, Runyan RB: Multiple transforming growth factor-beta isoforms and receptors function during epithelial-mesenchymal cell transformation in the embryonic heart. Cells Tissues Organs 2007;185:146-156.

51 Waltenberger J, Claesson-Welsh L, Siegbahn A, Shibuya M, Heldin CH: Different signal transduction properties of kdr and flt1, two receptors for vascular endothelial growth factor. J Biol Chem 1994;269:26988-26995.

52 Carmeliet P, Moons L, Luttun A, Vincenti V, Compernolle V, De Mol M, Wu Y, Bono F, Devy L, Beck H, Scholz D, Acker T, DiPalma T, Dewerchin M, Noel A, Stalmans I, Barra A, Blacher S, VandenDriessche T, Ponten A, Eriksson U, Plate KH, Foidart JM, Schaper W, Charnock-Jones DS, Hicklin DJ, Herbert JM, Collen D, Persico MG: Synergism between vascular endothelial growth factor and placental growth factor contributes to angiogenesis and plasma extravasation in pathological conditions. Nat Med 2001;7:575-583.

53 Fong GH, Rossant J, Gertsenstein M, Breitman ML: Role of the flt-1 receptor tyrosine kinase in regulating the assembly of vascular endothelium. Nature 1995;376:66-70.

54 LeCouter J, Moritz DR, Li B, Phillips GL, Liang XH, Gerber HP, Hillan KJ, Ferrara N: Angiogenesisindependent endothelial protection of liver: Role of vegfr-1. Science 2003;299:890-893.

55 He H, Gu XL, Venema VJ, Venema RC, Marrero MB, Caldwell RB: Vascular endothelial growth factor signals endothelial cell production of nitric oxide and prostacyclin through flk-1/kdr activation of c-src. Circulation 1999;100:483-483.

56 Terman BI, Dougher-Vermazen M, Carrion ME, Dimitrov D, Armellino DC, Gospodarowicz D, Böhlen P: Identification of the kdr tyrosine kinase as a receptor for vascular endothelial cell growth factor. Biochem Biophys Res Commun 1992;187:1579-1586.

57 Gerber HP, McMurtrey A, Kowalski J, Yan M, Keyt BA, Dixit V, Ferrara N: Vascular endothelial growth factor regulates endothelial cell survival through the phosphatidylinositol 3'-kinase/akt signal transduction pathway: Requirement for flk-1/kdr activation. J Biol Chem 1998;273:30336-30343.

58 Pedrazzini T: Control of cardiogenesis by the notch pathway. Trends Cardiovasc Med 2007;17:83-90.

59 High FA, Epstein JA: The multifaceted role of notch in cardiac development and disease. Nat Rev Genet 2008;9:49-61.

60 Zhou L, Azfer A, Niu J, Graham S, Choudhury M, Adamski FM, Younce C, Binkley PF, Kolattukudy PE: Monocyte chemoattractant protein-1 induces a novel transcription factor that causes cardiac myocyte apoptosis and ventricular dysfunction. Circ Res 2006;98:1177-1185.

61 Navab M, Imes SS, Hama SY, Hough GP, Ross LA, Bork RW, Valente AJ, Berliner JA, Drinkwater DC, Laks H, et al.: Monocyte transmigration induced by modification of low density lipoprotein in cocultures of human aortic wall cells is due to induction of monocyte chemotactic protein 1 synthesis and is abolished by high density lipoprotein. J Clin Invest 1991;88:2039-2046.

62 Taub DD: Chemokine-leukocyte interactions. The voodoo that they do so well. Cytokine Growth Factor Rev 1996; 7:355-376.

63 Liang J, Wang J, Azfer A, Song W, Tromp G, Kolattukudy PE, Fu M: A novel ccch-zinc finger protein family regulates proinflammatory activation of macrophages. J Biol Chem 2008;283:6337-6346.

64 Bonapace L, Coissieux MM, Wyckoff J, Mertz KD, Varga Z, Junt T, Bentires-Alj M: Cessation of ccl2 inhibition accelerates breast cancer metastasis by promoting angiogenesis. Nature 2014;515:130-133.

65 Roy A, Kolattukudy PE: Monocyte chemotactic protein-induced protein (mcpip) promotes inflammatory angiogenesis via sequential induction of oxidative stress, endoplasmic reticulum stress and autophagy. Cellular Signal 2012;24:2123-2131.

66 Vrotsos EG, Kolattukudy PE, Sugaya K: Mcp-1 involvement in glial differentiation of neuroprogenitor cells through app signaling. Brain Res Bull 2009;79:97-103.

67 Ebina M, Shimizukawa M, Shibata N, Kimura Y, Suzuki T, Endo M, Sasano H, Kondo T, Nukiwa T: Heterogeneous increase in cd34-positive alveolar capillaries in idiopathic pulmonary fibrosis. Am J Respir Crit Care Med 2004;169:1203-1208. 